\title{
Bathing facilities and health phronesis: tackling English obesity
}

Simon Huston ${ }^{1}$

\section{Abstract}

The Coronavirus pandemic has raised questions about public health system fragility or lack of health phronesis (practical wisdom). The UK is one of the unhealthiest developed nations on the planet with over $35 \%$ of its population projected to be obese by 2025. Notwithstanding, local sports infrastructure is patchy, raising the spectre of 'accumulation by dispossession'. To investigate English obesity problem and its eudaemonic impediments the study ignored lines of inquiry involving confectionary vested interests. Instead, it focused on bathing amenities that, since antiquity, signal civilisation. The phronetic bathing health research involved five sequential phases. First, the health issue was identified (1) and then bathing facilities put into historical context (2a). A structured literature review of contemporary facilities and health associations (2b) provided the backdrop for subsequent nomothetical (3a-e) and idiographic investigations (4a-c). The mixed research strands were finally synthesised (5). Statistical analysis of English local area standardised mortality (2013-2017) found a significant association with pool sparsity, controlling for deprivation, obesity and other environmental factors (3a-b). Longitudinal time series modelling of English swimming pool construction data since the Victorian era found that, recently, it has become erratic and diverges from its GDP and population growth fundamentals (3c-e). Idiosyncratically, the study considered three case studies, looking for qualitative insights (4). The closure of Bromley Lido in 1983 raises suspicions that short-termism or agency issues usurped public health phronesis (4a). In Cirencester, mistrust lingers about the privileged beneficiaries of local leisure service outsourcing (4b). An exemplary German pool complex in Ludenscheid illuminates comparative UK public bathing infrastructure deficiencies and intimates paradigm myopia or managerialist neglect (4c). Although the study is preliminary with acknowledged limitations, the literature reviews, nomothetic analyses and case studies impel phronetic deliberations to re-calibrate investment towards ecological public health and resilience in post-COVID 'doughnut' economy.

\footnotetext{
${ }^{1}$ Dr Simon Huston | Lecturer in Accounting | School of Economics, Finance and Accounting | Faculty of Business and Law Coventry University, Priory Street, Coventry, CV1 5FB

T: +44 (0) 2477657424 | E: ad4385@coventry.ac.uk
} 


\section{Introduction}

Beyond the immediate COVID-19 infectious pandemic, chronic diseases like obesity check human flourishing or eudaemonia ( $\varepsilon \dot{\delta} \delta \alpha \mu \mathrm{ovi} \alpha$ ). Worldwide, obesity growth has plateaued but its health and development repercussions remain concerning (NCD, 2017). Without integrated diagnostics and prevention, morbidity and its associated social burden impend (Park \& Lee 2020). Ecological public health professionalism, unlike managerialist short-termism or surreptitious 'nudge' ideology, involves

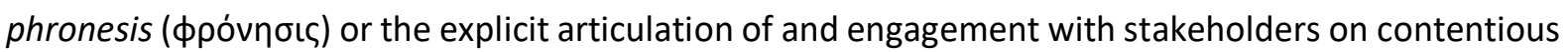
social and environmental choices (Leggett, 2014). Aristotle's Nicomachean Ethics (350 B.C, 6.5.6), was 'concerned with action in relation to the things that are good for human beings'. Its academic corollary is problem-driven, mixed-method research (Schram, Flyvbjerg \& Landman, 2013). Inequality in health, education or transport and sporting infrastructure are obvious fields for phronetic investigation to identify issues, extirpate vested interests and illuminate roadmaps for socially fruitful investment (Deem, 2000; Lang \& Rayner, 2012).

In terms of health, WHO data (2020) suggests an impending chronic disaster following in the wake of the infectious one (see Fig.1). COVID-19 induced death rates were, if not scandalous, shocking ${ }^{2}$ (ONS 2020) and illustrates health system fragility and spatial fragmentation. The health impacts of deprivation extends beyond mortality to morbidity or health constraints imposed by disease, injury or disability (Segen's Medical Dictionary, 2011). Some attribute crisis aetiology to confectionary or fizzy drinks behemoths like McDonalds and Coca Cola (incidentally the world's largest plastic polluter ${ }^{3}$ ) but Gibson (2008) only found inconclusive evidence.

\footnotetext{
${ }^{2}$ Most deprived areas 55.1 deaths per 100,000 population compared with 25.3 deaths per 100,000 population in the least deprived areas (ONS 2020)

${ }^{3}$ McVeigh, K. (2020) Coca-Cola, Pepsi and Nestlé named top plastic polluters for third year in a row (Guardian, 07 ${ }^{\text {th }}$ December 2020), accessed at: https://www.theguardian.com/environment/2020/dec/07/coca-cola-pepsiand-nestle-named-top-plastic-polluters-for-third-year-in-a-row (18/12/20).
} 


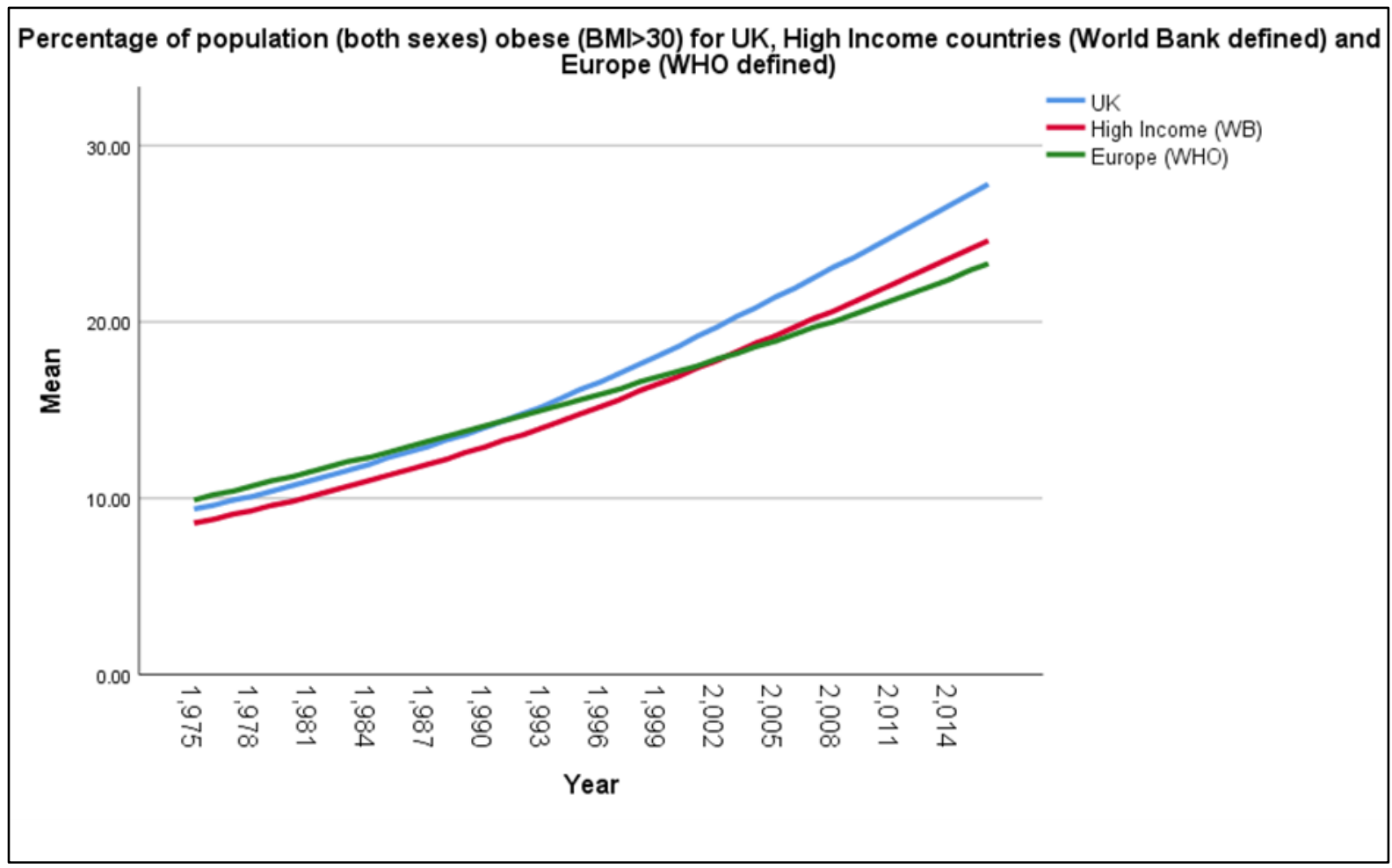

Figure 1: WHO time series data illustrating UK obesity issue (Global Health Observatory 2020)

Possible English health bottlenecks include dilatory food industry regulations, planning failures and sports infrastructure neglect. Swimming is the most popular sport in England yet, currently, $60 \%$ of English swimming pools are over 20 years old and one quarter have not been refurbished for 20 years (Sport England, 2018). Sport England estimates that complete replacement of these facilities would cost over $f 1.5$ billion. Chronic underinvestment belies bombastic bluster of 'harnessing the potential of sport for social good [in an] active nation' (HM Government, 2015, 6). Harvey $(2005 ; 2007)$ blames predatory capitalism for the inexorable public facilities underinvestment by way of stealthy dispossession (Das, 2017) but a complete answer to the ruckus impels structure and some perspective.

\section{Research questions and methodology}

The phronetic sequential research involved five phases. First, the study identified the health issue (1) and then put bathing facilities into their historical context (2a). A structured literature review of contemporary facilities and health associations (2b) provided the backdrop for subsequent nomothetical (3) and idiographic case study investigations (4) to answer three research questions:

- RQ1: Does the geospatial distribution of swimming facilities impact health? (Nomothetic). ( $\mathrm{H} 1_{0}$ : Pools is insignificant vs. $\mathrm{H}_{\mathrm{A}}$ : Pools is significant) 
- $\mathrm{RQ2}$ : Is the construction of swimming pools adequate for national health need? (Nomothetic).

( $\mathrm{H} 2_{0}$ : Forecast pool construction stable vs. $\mathrm{H} 2_{\mathrm{A}}$ : Forecast pool construction increases)

- RQ3: What policy learning emerges from idiosyncratic cases? (Idiographic \& qualitative)

Finally, in Phase V of the Bathing facilities and health phronesis investigation, the research triangulated its four strands for synthesis (see Fig. 2).

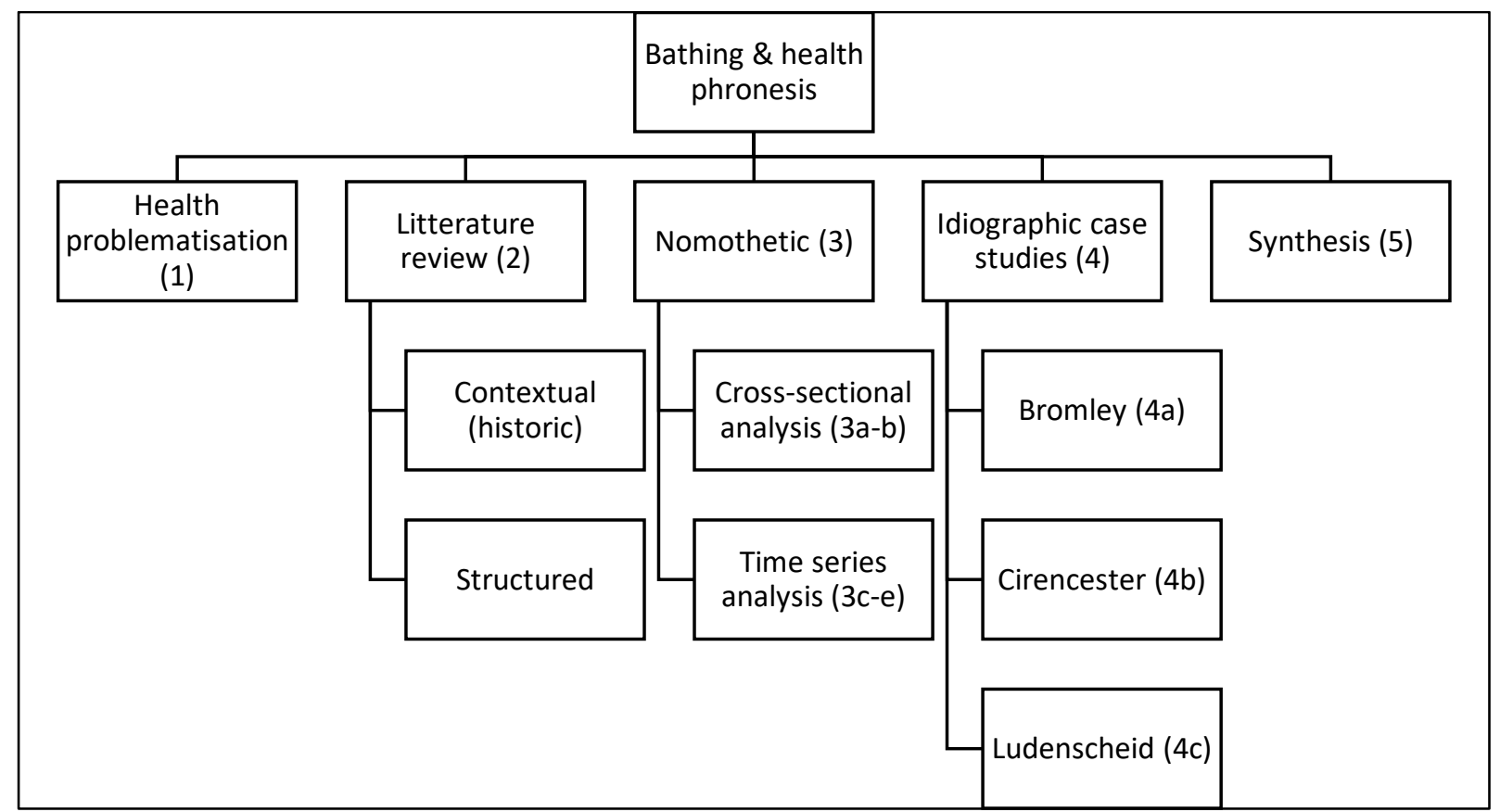

Figure 2: Pool phronesis research phases and stages

With the research roadmap clarified, before reviewing the contemporary health and sports facilities literature, the study reflected on bathing facilities in antiquity.

\section{Historical backdrop}

The classical period provides a useful touchstone to benchmark the current English health and bathing imbroglio. Influenced by the Greek gymnasium or palaestra (Yegül, 1992 \& 2010), the importance of baths in the Roman world is 'beyond dispute' (DeLaine, 1988, p. 11). For the Romans, public baths (thermae) were not only 'emblematic [for] civilization' but also technologically impressive (Gagliano et al., 2017 p. 704). Whist Marcus Aurelius (AD 121 - 180) in his VIII.XXIV meditation dismissed baths

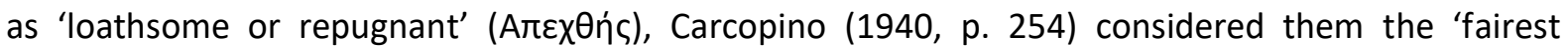
creations of the Roman Empire' (Ia plus belles créations de l'Empire Romain). Indisputably, baths were symbolically and culturally important for community cohesion (Zanker, 2010) and, arguably, conduits for cultural hegemony (Davis, 2015). 
Roman thermae were diverse, multi-faceted (public, private, military) and served cultural, cleansing, exercise and recreation functions (Nielsen, 1990; DeLaine, 1997; Fagan, 1999). Bathing facilities spread across the Empire, financed by patronage and modest entry fees (Meusel, 1960). Fully nude contiguous bathing emerged during the Principate but Hadrian restored prudery (Fagan, 1999; Ward, 1992). Deming (2020, pp. 152-161), following Carcopino (1940, p. 254) estimates that Roman bathing facilities grew from 170 baths in 33 BC to nearly 1000 'later', presumably at the height of the empire around the reign of Antoninus Pius (AD 138 to 161)? In Ostia alone, Krencker (1929) catalogued 20 facilities. Zanker (2010, p. 63) enumerates 956 balneia ( $\beta \alpha \lambda \alpha v \varepsilon \tilde{\alpha} \alpha)$ (small baths) in the Roman metropolitan region but these were dwarfed by the 23 grandiose imperial establishments (Platner, 1929). Trajan (109 AD), Caracalla (217 AD) Diocletian (306 AD) all bequeathed iconic imperial baths. The baths of Diocletian accommodated 3,200 bathers and covered $136,000 \mathrm{~m}^{2}$ or the extent of a typical provincial settlement such as Timgad in Algeria (Zanker, 2010). In the third century AD, the Emperor Caracalla's (AD 188 - 217) competed the Thermae Antoninianae Caracallae, the grandest of Rome's bathing facilities. Delaine (1997, p. 193) estimates that upwards of 13,100 worked on this mega urban project, costing between 1.2 billion denarii or $£ 1.3$ - $£ 9.8$ billion today ${ }^{4}$. When completed in $216 C E$, Caracalla's baths accommodated up to 10,000 people, although 1,600 was its norm. Its built area was 2.4 hectare (ha), around $24,000-26,477 \mathrm{~m}^{2}$, but its contiguous grounds extended 9-11 ha or $100,000 \mathrm{~m}^{2}$ (Fletcher, 1921; Oetelaar, 2014).

\footnotetext{
${ }^{4}$ Assumptions: 1D weighs $3.41 \mathrm{~g} @ 83.5 \%$ silver @ f0.39/g. Alternatively, assume 1D = national minimum wage $@ £ 8.20$
} 


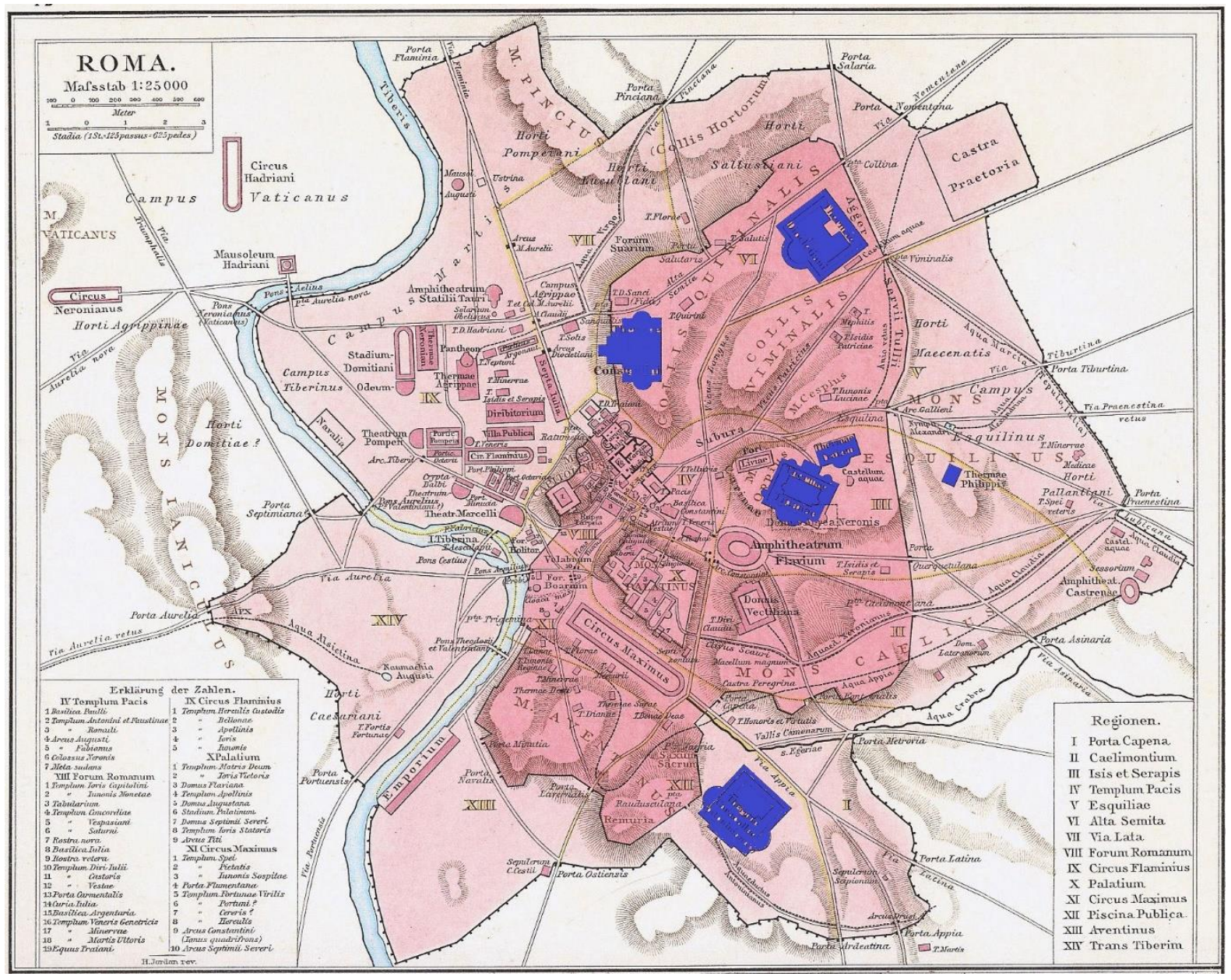

Figure 3: Indicative map, illustrating just a few of Classical Rome's 23 imperial thermae. (Sources: Author, Zanker, 2010 p. 62; Andree, R. 1886 in Allgemeiner Historischer Handatlas, Droysen. G. (Ed)).

Assuming, as Fig. 3 suggests, that Caracalla's Baths had similar dimensions as its peers, Rome's imperial bathing facilities occupied somewhere between $55.2-207$ ha or $4-15 \%$ of the $1,370-1400$ ha enclosed within its Aurelian Walls (Claridge, 1998, p. 24; Yawn, 2013). Clearly, in antiquity society resourced its public bathing facilities well. Historically informed, the study investigated the contemporary bathing situation.

\section{Structured literature review}

The research undertook a structured rather than systematic review of health, physical activity and facilities (swimming pools). Although the review involved several formal stages (access to databases, academic journals and industry or grey literature sources), in practice, it became iterative. Promising articles led to other fecund papers and the study leads snowballed. The multi-stage iteration provides some confidence that the study covered key swimming pool and health issues. 


\section{Databases and online platforms}

Initially, the study searched a university library database, looking for the term, 'swimming pools health' in peer-reviewed journals. The initial search returned 11,646 results but a public health restriction reduced this output to a more manageable 1,941 articles. When the filter 'swimming pools' was applied, only 399 results were returned. Often articles were incidental to the main purpose of this investigation. Irrelevant subjects included chlorination (33), disinfection (37), epidemiology (36), trihalomethanes, water quality (31) and environmental sciences (31). The incidental journal articles were removed, leaving topics related to 'health promotion', 'public health', 'exercise', 'humans' and 'swimming pools'. When the study imposed language (English and French) and date restrictions (2000-2020), 21 results emerged of which the most relevant seemed Giampaoli et al. (2014) who in a World Health Organization Bulletin that noted the increased use of recreational bathing facilities. It quoted figures from the European Union of Swimming Pool and Spa Associations that intimated that, in 2011, the continent had 5.7 million pools or one pool for every 150 inhabitants. But, the report focus was communicable diseases linked to pools, including cryptosporidiosis, giathiasis, leptospirosis, and legionellosis, bacterial and viral gastroenteritis. Even after this extensive literature filtering, most of the returned articles were spurious, spanning deaths by drowning in Australia (Staines 2017), the concentrations of trihalomethanes in Portuguese pools (Silva et al., 2012) or the 65\% of Italians who shower before swimming (Pasquarella et al., 2013). The study tweaked advanced features of Google Scholar to search the exact term 'swimming pools health' in the article title. Yet the search returned 104,000 items. However, the first line of these results intimated that most were thematic distractions, covering, for example 'chlorination', 'disinfection' or 'toxic chloramine' exposure etc. Next, the study accessed Scopus and ProQuest databases. For Scopus, using the terms 'swimming' AND 'pools' AND 'obesity' generated 37 results but only one by Stempski et al. (2015) had some bearing on the issue at hand. The US study found that, for low-income communities, swimming partnerships facilitated swimming to address health disparities. For ProQuest, search parameters were (sports facilities) AND (public health) OR obesity OR (swimming pools) which returned 495,805 results. Many were spurious, including, for example, papers on microbial water quality in indoor pools or preventing Cryptosporidium etc. A narrower search on (sports facilities) AND (public health), restricted to peerreviewed scholarly journals generated 38,783 results. The most promising top-listed papers included Heesch et al. (2014) who found socio-economic status, environmental perceptions, and psychological disposition influence cycling in Brisbane. Reimers et al. (2014) sampled 1,768 adolescents aged 1117 years old in 161 German communities and used GIS to compute distances to the nearest sports facilities. They assessed sports participation and found that distance from sports activities, moderated by urbanization, influenced activity. However, proximity to tennis courts or indoor pools was not associated with participation in tennis or water sports, respectively, probably because income barriers 
restrict access to private facilities. Wicker et al. (2013) analysed the impact of sport infrastructure on sport participation based on Becker's household theory (1965) that sport participation is a function of individual choice and available infrastructure. These authors telephoned 11,175 people in Munich and geocoded sport infrastructure. Multi-level analyses showed that swimming pool or sport field access influenced sport participation.

In 2013, Australian researchers led by Eime reviewed the sports literature between 1990 and 2012 . They identified 3,668 articles but analysed 11 appropriate ones that met Downs \& Black (1998). The Australians found many psychological and social health benefits of sport, including improved selfesteem and social interaction as well as reduced stress. Club-based and team-based sport participation appears particularly beneficial. Subsequently, in 2017 Eime et al. conducted their own empirical sport participation investigation, using a sample of 488,693 respondents in 79 Victorian LGAs (Local Government Area). These researchers found a consistent pattern of positive associations between the participation rate and facility provision.

\section{Journals}

The study identified relevant journal papers that investigated the association between exercise, swimming pools and health. The research scanned platforms, databases and journals, using terms 'swimming pools and health', 'swimming pools and mental health' or 'health and physical activity'. The study only considered articles from acceptable journals with over 100 citations, published after 2000.

In the general health field, the study found a couple of particularly useful systematic health reviews. For example, van Sluijs et al. (2007) gauged the effectiveness of interventions to promote physical activity in children and found limited evidence of effective environmental and policy interventions. Park et al (2012) noted consistent evidence of associations between childhood BMI and cardiovascular outcomes, but was unclear whether effects persisted, independently of adult BMI. Whilst, mortality in deprived locales can be double that of affluent ones, (ONS, 2020; Steel et al., 2018), personal disadvantage is a more significant for mortality compared to spatial communal factors (Sloggett \& Joshi, 1994). Notwithstanding, The Marmot Review (Marmot et al 2020) attributes pandemic outcome disparities in England to socioeconomic and health inequalities.

For facilities, most of the geospatial studies isolated were micro investigations on specific settlements and confirmed generally understood linkages. Other studies confirmed the intuitively obvious link between facilities and health, notwithstanding the influence of other micro spatial or macro factors. Jimenez et al. (2019) used longitudinal New England data $(n=671)$ with 46-years of follow-up and found that neighbourhood socioeconomic status influenced cardiovascular disease, controlling for 
blood pressure, body mass index (BMI), age, sex, race/ethnicity, individual and parental socioeconomic status. They found that living in a socioeconomically disadvantaged neighbourhood early in life and in adulthood was associated with blood pressure and BMI. In (2004) Fisher et al. used a cross-sectional multilevel analysis to investigate the influence of neighbourhood characteristics on self-reported physical activity for 582 older (>65 years) adults in 56 Portland on the western seaboard of the United States. As individuals nested in neighbourhoods, the authors used two-stage multilevel structural-equation-modelling and found that neighbourhood influenced physical activity. When individual-level variables were controlled, neighbourhood-level variables like social cohesion substantially influenced physical activity.

\section{Industry literature}

The study interrogated World Health Organisation (WHO) data looking for sources related to obesity and found an authoritative seminal longitudinal study in the Lancet (NCD, 2017) that pooled analysis of 128.9 million cases to generate a body-mass index from 1975 to 2016.

According to Public Health England (2017), in 2015 63\% of English adults were overweight (BMI>25) or obese (BMI>30). For men, obesity increased from 13.2\% in 1993 to $26.9 \%$ in 2015 while for women the comparable figures were from $16.4 \%$ to $26.8 \%$. In 2015, almost one third of English children (more precisely $34.1 \%$ aged 10 to 11 ) were overweight or obese and the trend is upwards. Each year, obesity kills 30,000 people and reduces the lifespan of its victims by 9 years of life. More is spent annually ( 66.1 billion 2014 - 2015) treating obesity-related illness than is spent on the police, the fire service and the judicial system combined. Perceived discrimination compounds the obesity crisis (Jackson \& Steptoe 2017).

\section{Literature conclusion}

The multi-stage, iterative review of the health facilities and bathing literature was extensive rather than narrow. It spanned public health issues, bathing facilities in antiquity and area studies on the impact of facilities. By comparison with antiquity, contemporary bathing provision appears somewhat patchy if not depleted. On the health front, obesity emerges as a chronic problem, crippling the nation beyond the COVID-19 pandemic. The literature found clear associations between BMI and chronic disease but some uncertainty involving appropriate policy treatment. Due to confounding variables, the scientific evidence for impact of public health asset intensification on chronic disease remains uncertain. The literature review supports common sense that swimming or other sport participation brings physical and psychological benefits, notwithstanding some chemical, bacteriological or injury risks. The literature repeatedly links excess morbidity with spatially fragmented deprivation. Affluence and sports facility accessibility influence physical activity. For serious public health improvements, the review clearly points to the need to attenuate deprivation on some systematic 
basis. Even so, the literature suggests that research into the association between swimming pools and mortality or the influence of bathing facilities investment on health could provide some fruitful policy directions.

\section{Nomothetic (quantitative) investigations}

\section{Approach}

The third phase of the sequential mixed methods Bathing facilities and health phronesis research involved five nomothetic (statistical) investigations, conducted in two stages. In the first crosssectional stage, the study used factor analysis to explore (3a) and regression to analyse English mortality and its covariates (3b). During the second stage of this third (nomothetic) phase of the research, the study analysed 120 years of English pool construction data using autoregressive distributed lag models - ARIMA (3c), ADL (3d) and ECM (3e).

\section{Data}

The study sourced data from Sports England (SE), Office of National Statistics (ONS), WHO, Consumer Data Research Centre (CDRC) and the Bank of England (BoE). Below are the variables, their source and their expected inter-relationship.

\section{Cross sectional analysis}

Deaths (DV, $\left.Y_{d}\right)$ : cross-sectional analysis ( $3 a$ \& $\left.3 b\right)$ dependent variable $(D V$,$) . Sourced from ONS$ standardised mortality ratio (2013-2017). Observed total deaths from all causes (by five year age and gender band) as a percentage of expected deaths. Mortality in Richmond upon Thames is below ageadjusted expectation (77.3\%) compared to Middlesbrough where actual deaths exceeded standard expectations by over $40 \%(143 \%)$.

Access Leisure (IV, $\mathrm{X}_{1}$ ): reflects accessibility to 727 leisure centres, swimming baths or 2,738 health clubs in kilometres. Sourced via SE (2020) from Liverpool University's Consumer Data Research Centre (CDRC), Access to Healthy Assets and Hazards (AHAH) index (CDRC, 2020). AHAH integrates retail environment, health services, physical environment and air quality to generate an overall summary of locales environmental health (Green et al., 2016). The Isles of Scilly (74.3) or Melton Mowbray (19.9) have relatively poor access compared to City (0.3), Kensington and Chelsea (0.4) or Islington (0.5). Ceteris paribus, easier access should improve health so the coefficient expectation for $X_{1}$ is positive (lower km or easier access, then lower mortality or if $X_{1} \downarrow, \rightarrow Y_{d} \downarrow$

Obesity (IV, $\mathrm{X}_{2}$ ): percentage of adult population with a body mass index (BMI) of $30 \mathrm{~kg} / \mathrm{m} 2$ or higher, age-standardized sourced from WHO 2389 NCD_BMI_30 (2020). In Kensington and Chelsea it was $14 \%$ compared to, for example Gateshead at $30.7 \%$. Coefficient expectation for independent variables 
(IV), $X_{2}=$ Obesity, is positive as more excess obesity is expected to increase excess deaths. If $X_{2} \uparrow, \rightarrow$ $Y_{d} \uparrow$

Deprivation (IV, $\mathrm{X}_{3}$ ): deprivation score for English small areas, sourced from Index of Multiple Deprivation (2019). To generate the index, deprivation indicators across seven domains (income, employment, education/training/skills, health and disability, crime, housing, and environment) are, adjusted, combined, ranked, transformed and weighted. A lower rank indicates higher deprivation (e.g. Birmingham and Solihull $=4,191$ vs. Windsor 26,634 (mean 17,460). Expectation is that if $X_{3} \uparrow$, $\rightarrow Y_{d} \downarrow$

Environment (IV, $\mathrm{X}_{4}$ ) measures accessible blue and green space, sourced via SE (2020), the data constitutes an element of AHAH (2017) (see above). Hackney had the worst environmental score (0.2) compared to Mid Suffolk (60.4). The expectation is that environment coefficient will be negative as more green or blue space access should reduce mortality ceteris paribus so if $X_{4} \uparrow, \rightarrow Y_{d} \downarrow$

Pools (IV, $\mathrm{X}_{5}$ ): reflects pools per 10,000 in 2018 (latest available data). Data extracted from Active Places Power (APP) SE's analytical interactive web mapping and reporting tool. APP references England's most authoritative sport facility and club database. The study then used ONS population data to compute the number of pools per 10,000 residents in each locales. Locales comprised 343 English local authorities (county councils, district councils, unitary authorities, metropolitan districts and London boroughs) but also SE Active Partnerships (45) and Local Delivery Pilots (11). The study acknowledges the need to audit the geospatial integrity of pool data (see study limitations). Expectations is that if $X_{5} \uparrow, \rightarrow Y_{d} \downarrow$

Time series analysis

Pools constructed ( $P C \& \triangle P C)$ : English swimming pools constructed each year during a 120 year period since 1900, sourced form Sports England: Active Places Power (2020) database.

English output (GDP \& $\triangle$ GDP): Bank of England millennium of macroeconomic data UK (2017) provides historical macroeconomic and financial statistics. Based on the Blue Book 2016, it includes historical data from Broadberry et al. (2015), cross checked against Mitchell (1988).

English population (Pop \& $\triangle$ Pop): English population and population growth 1900-2020, sourced from Office for National Statistics (ONS): Total population (2018). ONS England population mid-year estimate (2019) shows mid-year estimates of total population of area (all ages and genders). English population estimates 2000-2018 were cross checked against ONS Population growth in the United Kingdom (2018). 


\section{Cross-sectional analysis}

To answer the first research question (RQ1: Does the geospatial distribution of swimming facilities impact health?), the study applied insights from the medical literature for its explanatory framework. Mortality is influenced by a matrix of personal, social and environmental factors, in particular obesity, deprivation and other cross sectional environmental factors. To explore the cross sectional data, the study conducted factor analysis, using principal components extraction (3a). Later, a regression analysis (3b) found that swimming pool density was a significant influence on mortality.

The principal components analysis (PCA) revealed no eigenvalues close to 0 that provided some comfort about indicator collinearity.

Table 1: Factor analysis - extraction method Principal Component (3a)

\begin{tabular}{|c|c|c|c|c|c|c|}
\hline \multirow{2}{*}{$\frac{\text { Component }}{3 a}$} & \multicolumn{3}{|c|}{ Initial Eigenvalues } & \multicolumn{3}{|c|}{ Extraction Sums of Squared Loadings } \\
\hline & Total & $\%$ of Variance & Cumulative \% & Total & $\%$ of Variance & Cumulative \% \\
\hline 1 & 2.317 & 38.623 & 38.623 & 2.317 & 38.623 & 38.623 \\
\hline 2 & 1.436 & 23.935 & 62.558 & 1.436 & 23.935 & 62.558 \\
\hline 3 & .961 & 16.018 & 78.576 & & & \\
\hline 4 & .694 & 11.568 & 90.144 & & & \\
\hline 5 & .377 & 6.284 & 96.428 & & & \\
\hline \multirow[t]{3}{*}{6} & .214 & 3.572 & 100.000 & & & \\
\hline & \multicolumn{2}{|c|}{ Component } & & & & \\
\hline & 1 & 2 & & & & \\
\hline Access Leisure & .382 & .627 & & & & \\
\hline Obesity & -.551 & .672 & & & & \\
\hline Deprivation & .885 & -.048 & & & & \\
\hline Environment & .508 & .631 & & & & \\
\hline Deaths & -.909 & .164 & & & & \\
\hline Pools & -.006 & -.406 & & & & \\
\hline
\end{tabular}

PCA extracted two main components that explain over $62 \%$ of variable fluctuations. Component 1 seems to capture relatively privileged locales, loading strongly and negatively on obesity and deaths as but positively on environmental variables and deprivation index. It is perhaps more intuitive to think of Deprivation as an indicator of privilege, given it rises as conditions improve. Component 2 perhaps captures semi-rural and rural locales with access to green and blue space, a dearth of sports infrastructure and endemic obesity. The upshot of the factor exploration reinforces the literature that obesity is a key mortality covariate in a geographically and socially fragmented English landscape. 
In the second stage (3b) of the cross sectional analysis, the study regressed deaths against covariates of independent variables (IVs) suggested by the health and medical literature.

$$
Y_{t}=\propto+\beta X_{1}+\beta_{2} X_{2}+\beta_{3} X_{3}+\beta_{4} X_{4}+\beta_{5} X_{5}+\varepsilon(3 b)
$$

Where:

$Y_{t}=$ English LGA standardised mortality ratio (2007-13)

$X_{1}=$ Access to leisure (coefficient expectation $>1$, as easier access/shorter distance, lowers excess mortality)

$\mathrm{X}_{2}=$ Obesity (coefficient expectation $>1$, as higher excess obesity increases excess mortality)

$X_{3}=$ Deprivation (coefficient expectation $<1$, as low score indicates worse deprivation and expected increase in excess deaths)

$\mathrm{X}_{4}=$ Environment (coefficient expectation $<1$ as better environment should reduce mortality).

$X_{5}=$ LGA Pools per 10,000 (coefficient expectation $<1$, as higher pool density should cut excess mortality. Null hypothesis for RQ1: $\mathrm{H} 1_{0}: \beta_{5}=0$

Table 2 presents regression descriptive statistics.

Table 2: Cross sectional descriptive and regression statistics (3a \& 3b)

\begin{tabular}{l|r|r}
\hline \multicolumn{1}{c|}{ Variable } & \multicolumn{1}{c|}{ Mean } & \multicolumn{1}{c}{ Std. Deviation } \\
\hline Deaths & 100.6284 & 12.29323 \\
\hline Access Leisure & 4.2546 & 4.40092 \\
\hline Obesity & 24.1951 & 2.90186 \\
\hline Deprivation & 17460.3383 & 5146.47736 \\
\hline Environment & 23.4262 & 10.63328 \\
\hline Pool/10,000 & 1.0196655 & 1.16483852 \\
\hline Valid cases & 405 & \\
\hline Shapiro-Wilk & 0.982 & \\
\hline
\end{tabular}

Although the Shapiro-Wilk (SW) test was highly significant $(p<0.001)$, suggesting data significantly deviate from a normal distribution. As the study analysed all, rather than a sample of, English locales, the Central Limit Theorem does not apply but with the large number of cases ( $N=404)$, SW sometimes detects trivial normality departures. In short, regression and t-tests remain robust even if not always BLUE (best linear unbiased estimator). 
Case wise diagnostics pulled out three outliers. The first was Hackney, where deaths were well below those modelled by the regression line (residual -21.736). Gentrification could provide a plausible explanation for the negative residual of this central London suburb. At the other end of the spectrum and country was Middlesbrough, a de-industrialised locales whose toxic chemical industry legacy could explain higher than modelled death rate (residual 25.046). In terms of pools per 10,000 residents, the City of London was an anomaly (19.52) compared to the mean (1.01) (see Fig. 4). This is likely due to prevalence of hotel swimming pools or stockbroker underground ones.

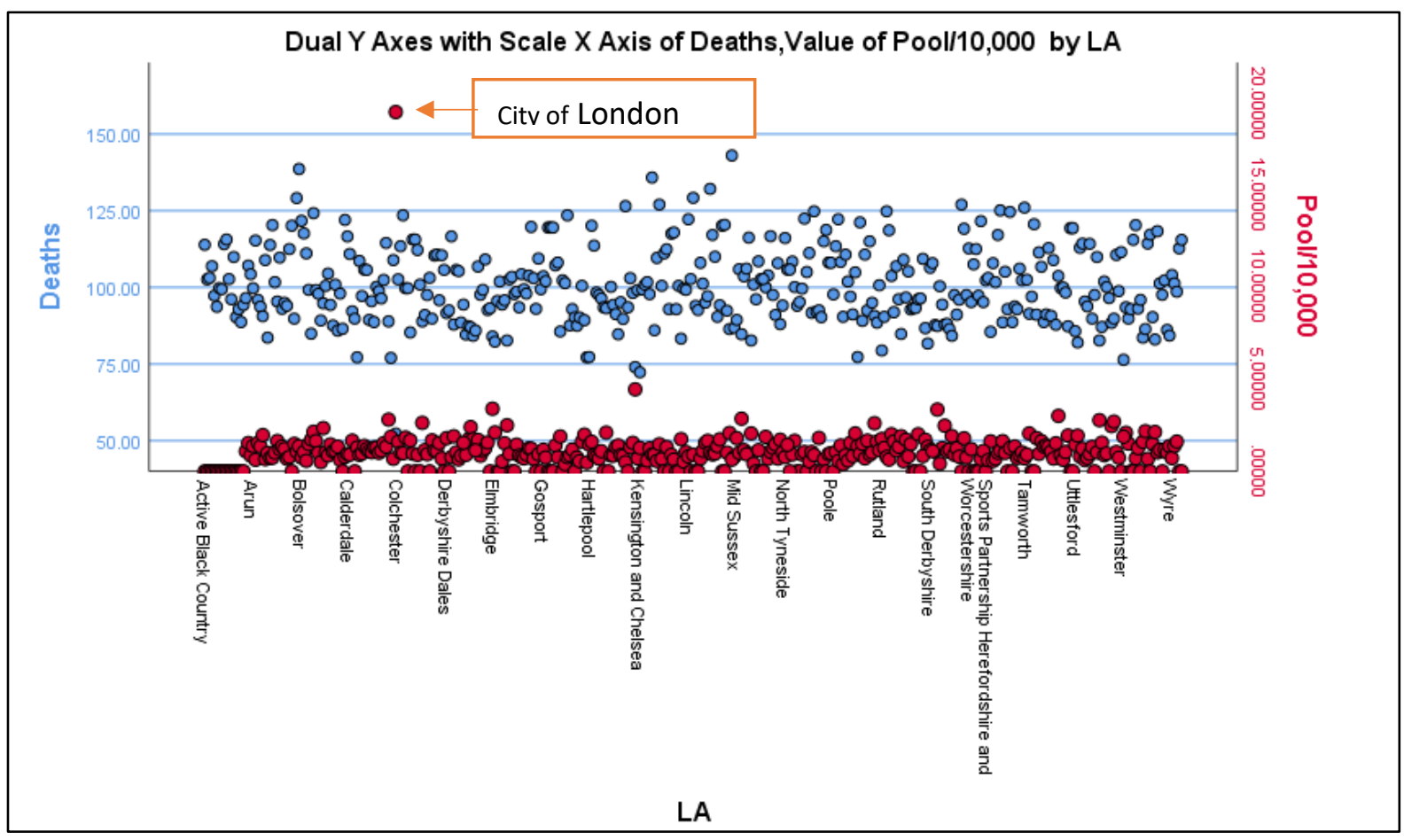

Figure 4: Fluctuations of deaths and pool density, illustrating London outlier in terms of pool density

The study ran graphical and diagnostic tests to check linear regression assumptions compliance (linear fit without influential observations and random errors that are independent, normally distributed with an expected zero mean and constant variance). The histogram of residuals (Fig. 5) and PP plot of standardised residuals (Fig. 6) illustrate an acceptable residual regime, normally distributed and with observed and fitted model deviations in line with expectations. 


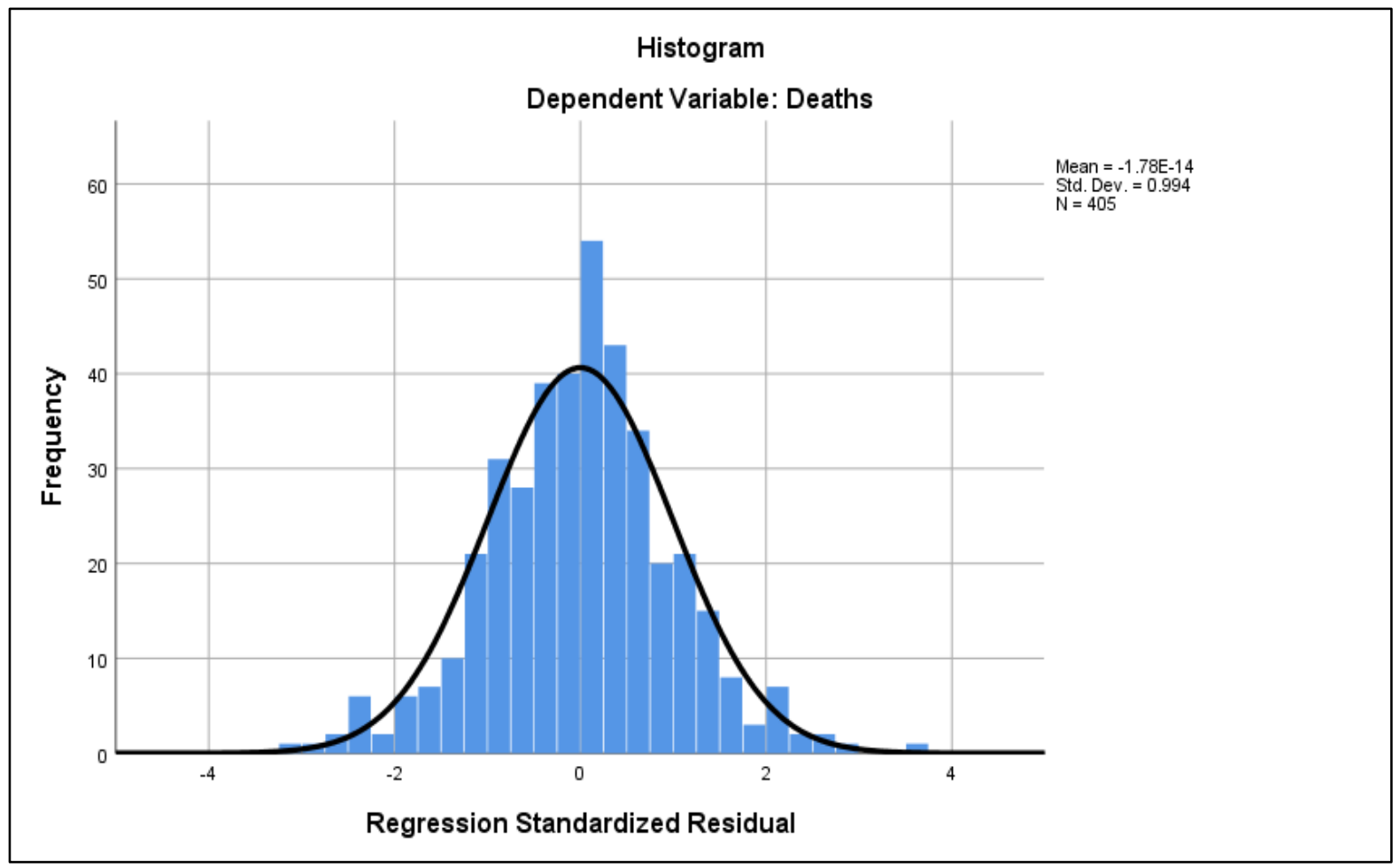

Figure 5: Regression residual histogram, illustrating normal distribution

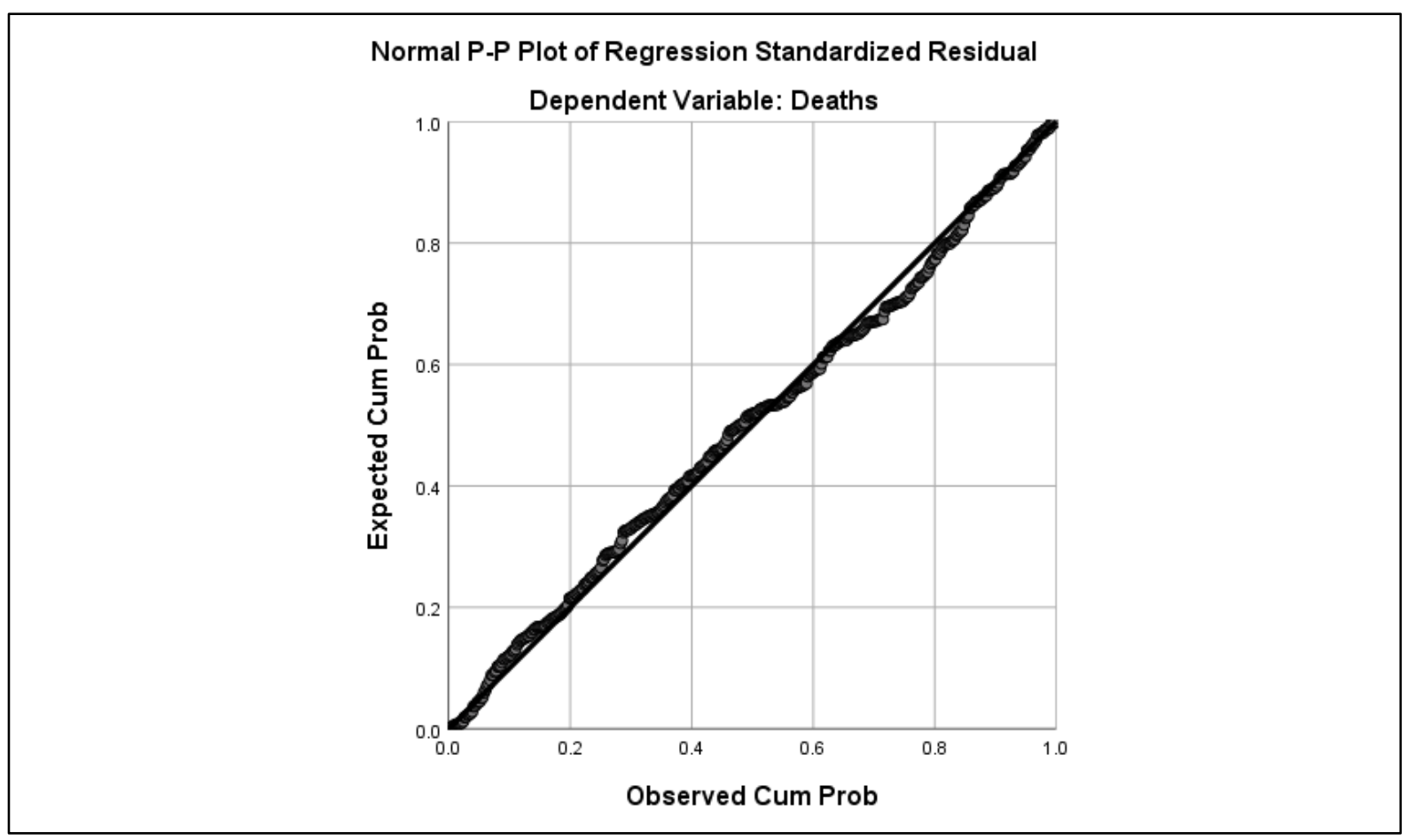

Figure 6: PP Plot of regression standardised residuals, confirming residuals are normally distributed

To check for residual variance constancy, the study plotted standardised residuals (ZRESID) against predicted values (PRED) which generated a reasonably random scatter (Fig. 7). 


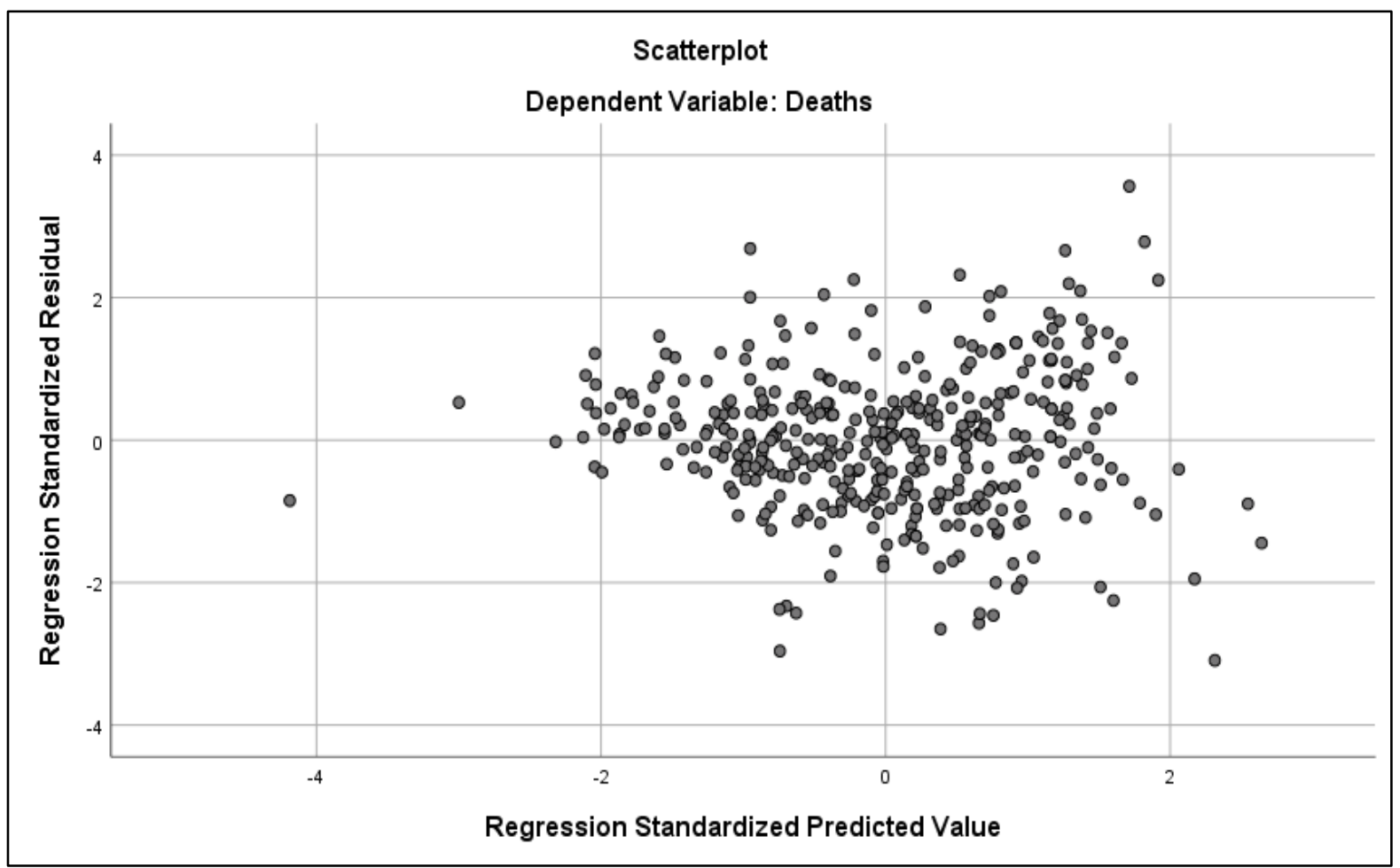

Figure 7: Standardised residuals scattergram, illustrating broadly acceptable DV variance fluctuation, although slight 'megaphone' or fanning of error dispersion as locales mortality increases (heteroscedasticity)

Graphs of key IV against the DV confirmed linear regression suitability, notably for Deprivation variable in explaining the variability in Deaths.

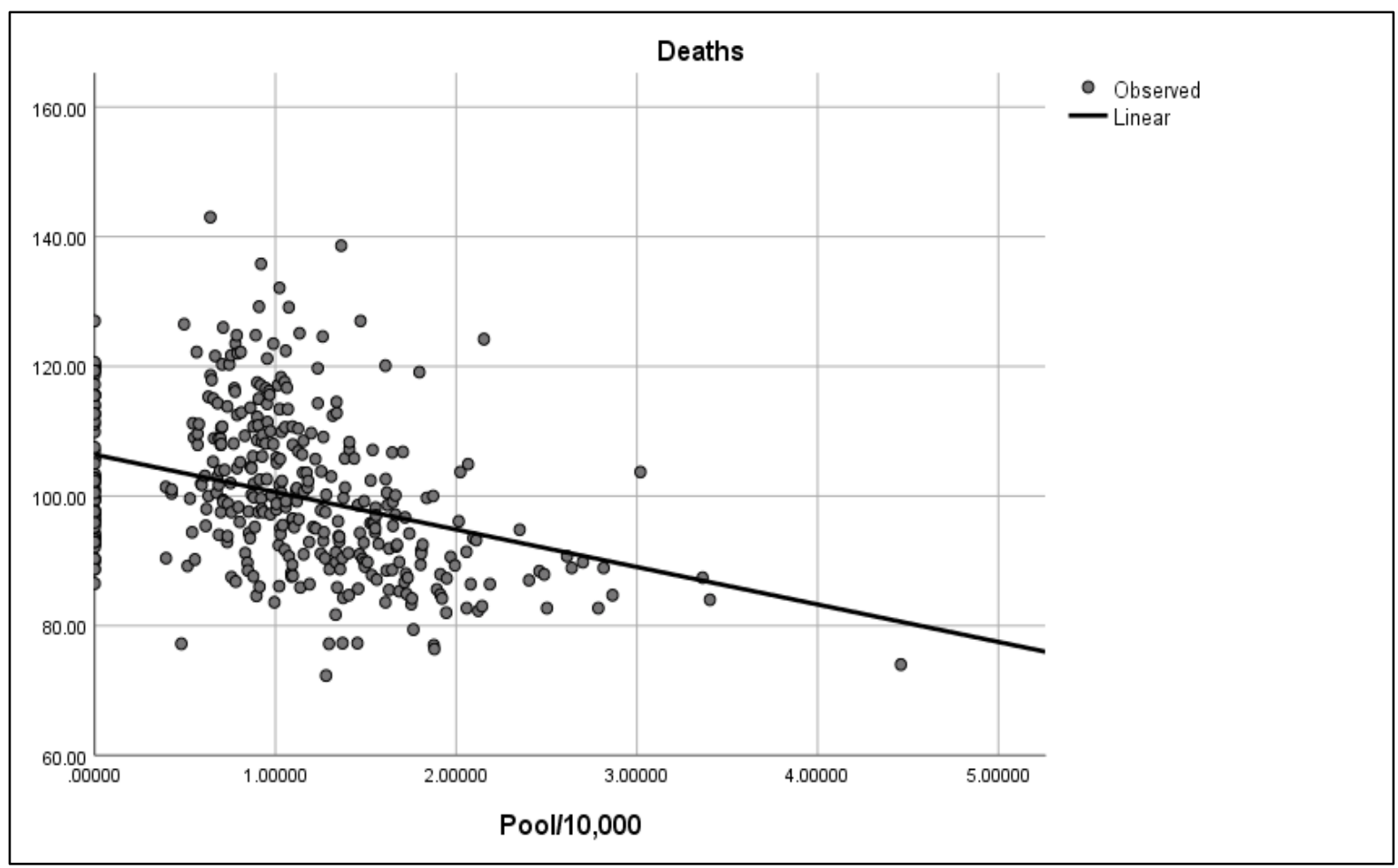

Figure 8: Scatterplot of deaths and pool density with City of London outlier removed 
Graphical diagnostics (Fig. 8) suggests locales pool density mitigates excess deaths but, ceteris pariubs, the influence of pool facilities is markedly less pronounced compared to the deprivation IV (Fig. 9).

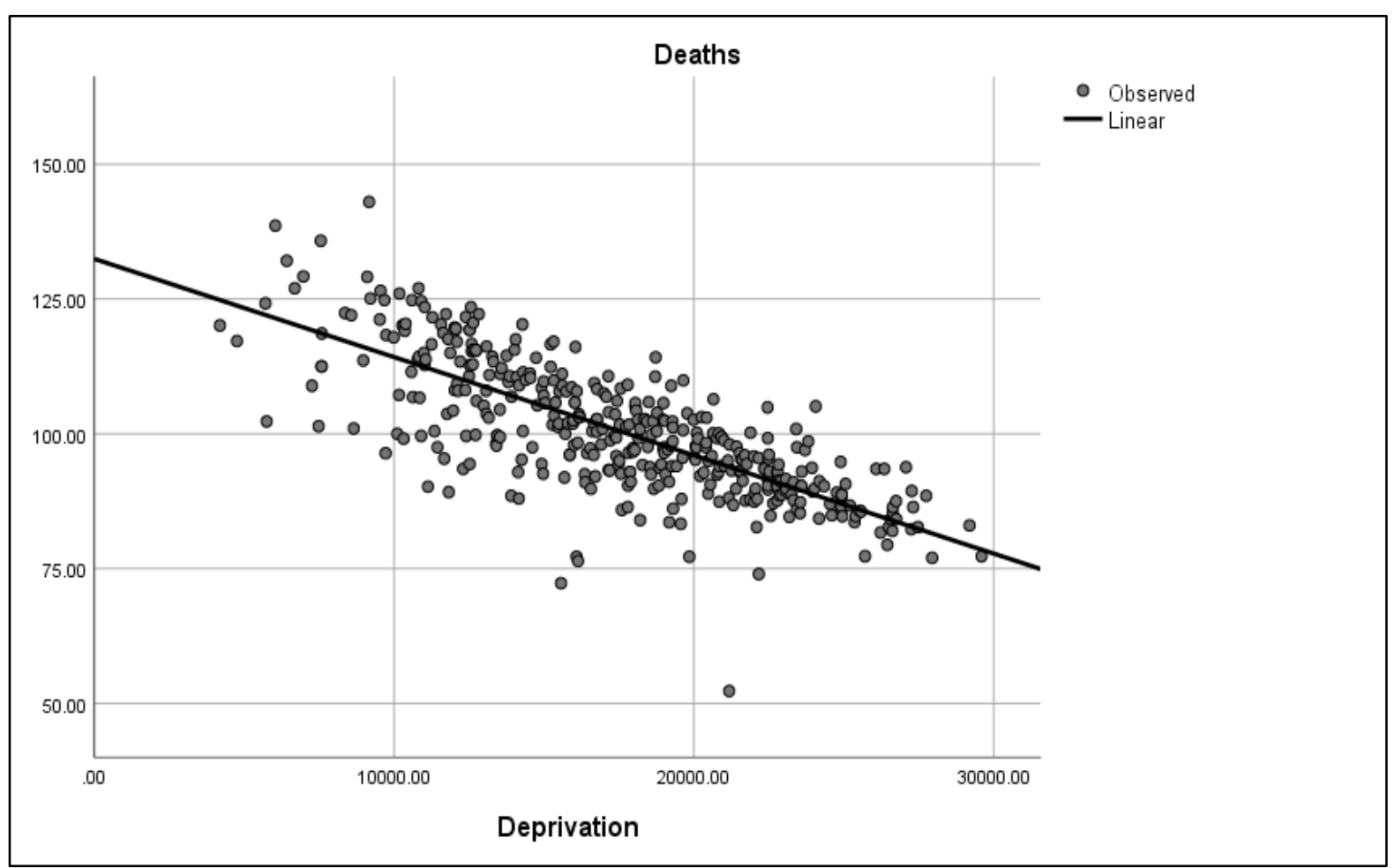

Figure 9: Strong impact of deprivation on mortality

Multicollinearity or high correlations between IVs can render regression coefficients unstable, unreliable and lower statistical power. Variance inflation factors (VIF) though were acceptable) see Table 4). VIF estimates how much IV interdependence inflates coefficient variance and a VIF limit of 2.50 is customary. The standard error (s.e.) of regression coefficients appear relatively small. An examination of Pearson cross-correlations (Table 3) confirms the literature that Obesity and Deprivation are strongly associated with mortality. Curiously, Access and Pools only have a Pearson correction of 0.153 despite pools inclusion in the former. The positive association between the Environment and Access Leisure reflects the increased distance from leisure facilities in the suburbs and rural locales. Counter intuitively, the negative correlation between Deaths and Access suggests as distance to facilities decreases, excess deaths increases. Probably, the leisure access variable reflects not only the benefits of facilities but also the confounding influence of industrial and suburban blight but, as noted, multicollinearity diagnostics provides some assurance that confounding impact is acceptable. 
Table 3 Correlations (Pearson Correlation)

\begin{tabular}{l|r|r|r|r|r|r}
\hline & \multicolumn{1}{|c|}{ Deaths } & \multicolumn{1}{c|}{$\begin{array}{l}\text { Access } \\
\text { Leisure }\end{array}$} & Obesity & Deprivation & Environment & Pool/10,000 \\
\hline Deaths & 1.000 & -.224 & .532 & -.763 & -.321 & -.360 \\
\hline Access Leisure & -.224 & 1.000 & .066 & .180 & .398 & .153 \\
\hline Obesity & .532 & .066 & 1.000 & -.411 & .124 & -.255 \\
\hline Deprivation & -.763 & .180 & -.411 & 1.000 & .398 & .230 \\
\hline Environment & -.321 & .398 & .124 & .398 & 1.000 & .101 \\
\hline Pool/10,000 & -.360 & .153 & -.255 & .230 & .101 & 1.000 \\
\hline
\end{tabular}

The $\mathrm{F}$ statistic in Table 4 is significant and indicates the regression makes sense and explains fluctuations of standardised death rates significantly better than the mean (restricted model). The regression generated an adjusted $R^{2}$ of 0.673 so that it accounts for over $2 / 3^{\text {rd }}$ of the variation in deaths across England. 
Table 4: Cross sectional regression statistics (3a)

DV Deaths with Predictors: (Constant), Pool/10,000, Environment, Obesity,

Access Leisure, Deprivation

\begin{tabular}{|c|c|c|c|c|c|c|c|c|}
\hline & $\mathrm{R}$ & R Square & $\begin{array}{l}\text { Adjusted R } \\
\text { Square }\end{array}$ & \multicolumn{2}{|c|}{$\begin{array}{c}\text { Std. Error of the } \\
\text { Estimate }\end{array}$} & & & \\
\hline & $.823^{a}$ & .677 & .673 & \multicolumn{2}{|r|}{7.02895} & & & \\
\hline & $\begin{array}{l}\text { Sum of } \\
\text { Squares }\end{array}$ & $d f$ & Mean Square & $\mathrm{F}$ & Sig. & & & \\
\hline Regression 3a & 41340.840 & 5 & 8268.168 & 167.351 & .000 & & & \\
\hline Residual & 19713.043 & 399 & 49.406 & & & & & \\
\hline \multirow[t]{2}{*}{ Total } & 61053.883 & 404 & & & & & & \\
\hline & Expected sign & $\mathrm{B}$ & Std. Error & Beta & $\mathrm{t}$ & Sig. & Tolerance & VIF \\
\hline (Constant) & & 100.397 & 4.150 & & 24.190 & .000 & & \\
\hline $\begin{array}{l}\text { Access Leisure } \\
\left(\mathrm{X}_{1}\right)\end{array}$ & $>1$ & -.245 & .087 & -.088 & -2.803 & .005 & .826 & 1.211 \\
\hline Obesity $\left(X_{2}\right)$ & $>1$ & 1.184 & .144 & .279 & 8.225 & .000 & .701 & 1.426 \\
\hline Deprivation $\left(\mathrm{X}_{3}\right)$ & $<1$ & -.001 & .000 & -.569 & -15.763 & .000 & .621 & 1.611 \\
\hline $\begin{array}{l}\text { Environment } \\
\left(\mathrm{X}_{4}\right)\end{array}$ & $<1$ & -.092 & .041 & -.080 & -2.279 & .023 & .659 & 1.517 \\
\hline Pool/10,000 (X5) & $<1$ & -1.434 & .317 & -.136 & -4.517 & .000 & .895 & 1.117 \\
\hline
\end{tabular}

Model coefficients are all significant at the $5 \%$ confidence level. There is strong evidence that leisure access, obesity, deprivation and pool density are significantly associated with mortality $(p<0.01)$ but only some evidence $(p=0.023)$ that the environment is significant. All have the expected signs except for leisure access, already flagged as a variable with confounding issues. Variance inflation factors (VIFs), that quantifies multicollinearity severity, are under the generally accepted 2.5 threshold. Due to IV measurement variability, the standardised coefficients provides most useful insights into the relative impact of the variables and suggests, unsurprisingly, a strong association between deprivation and excess deaths. In fact a reduction in deprivation rank of one standard deviation (SD) or 5146.47, increases locales excess deaths by more than half a SD (-0.569). Given deaths SD of $12.293 \%$ (see Table 2), this would augment excess mean deaths by almost 7\%. The results confirm the literature, that deprivation and obesity are the main predictors of excess deaths. Surprisingly, pool density seems to have more of an impact than the two environmental variables, with a standardised $\beta$ of -0.136 . The unstandardized pools coefficient of -1.434 suggests that if another pool were built per 10,000 residents, one could expect an associated reduction in excess mortality over $1.4 \%$. The evidence from the cross sectional regression analysis ( $3 \mathrm{~b}$ ) supports the alternative hypothesis, $\mathrm{H} 1_{A}$, that pool density significantly influences excess mortality in England. 


\section{Time series analysis}

The time series analysis sought to answer RQ2: Is the construction of swimming pools adequate for national health need? (Nomothetic). The study ran three time series models where pools constructed (PC) or changes in this dependent variable $(\triangle P C)$ were fitted to lag values of itself and other predictors, covariates or independent variables (IVs):

- Autoregressive Integrated Moving Average - ARIMA (3c)

- Autoregressive Distributed Lag - ADL (3d)

- Error Correction Model - ECM (3e)

Fig. 10 illustrates the evolution of bathing facilities construction in England over the past 120 years (1900-2020).

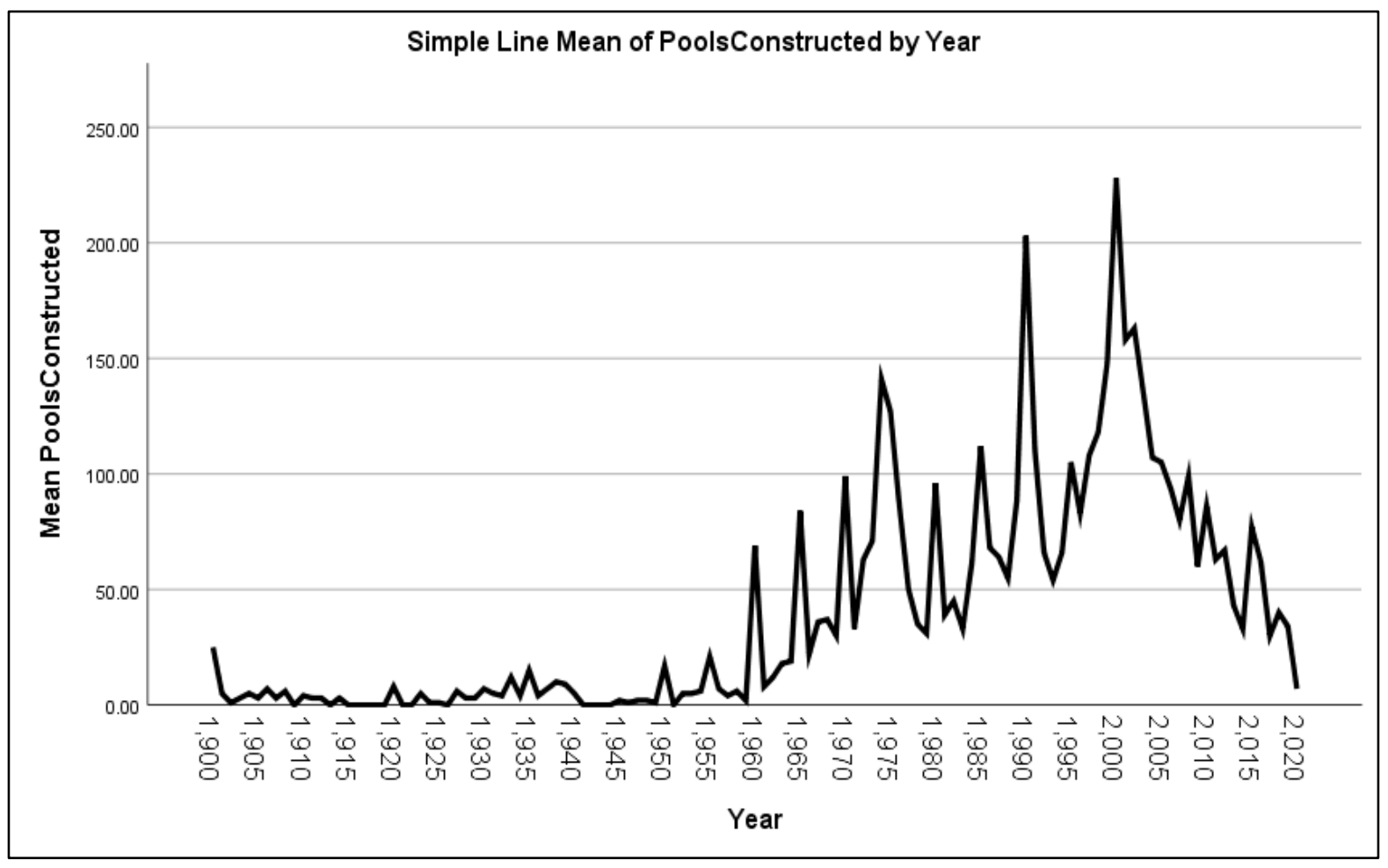

Figure 10: Pool construction in England and Wales (Sports England, 2020)

It is clear from Fig. 10 that pool construction in England has fluctuated widely. Technically, the pools series appears non-stationary because its mean and variance vary. Autoregressive models use current and past values of DV and IV to explain pool construction activity. However, deterministic and stochastic trends mean residuals are autocorrelated and OLS modelling assumptions violated. Detrending removes deterministic (time based) whilst differencing removes stochastic trends. A differenced stochastic process becomes stationary so that autocorrelation functions die out rapidly. Whilst inspection (Fig. 10) guided initial series diagnosis, the study formally tested the association of 
lagged pool construction ( $P C_{t-1}$ ) with current period activity $\left(P C_{t}\right)$. Formally, whether for equation $P C_{t}$ $=\alpha+\varphi P C_{t-1+\varepsilon}$ i.e. (3c) the coefficient $\varphi=1$ (random walk with drift). When a shock destabilises such a series, the unit root prevents reversion to equilibrium. However, because of the spurious regression issue, we cannot test $\varphi=1$ in $3 c$ directly. Instead, the study used the Dickey Fuller Test (DFT) procedure. $\triangle P C$ was regressed against $P C$ lagged by one period. $\triangle P C=\alpha+\theta P C_{t-1+\varepsilon},(3 d)$ - where $\theta=$ $\varphi$-1. For this differenced regression, if $\theta=0$, then $\varphi=1$ in $3 c$ and a unit root is present. For $3 d$, the DFT null hypothesis $\left(\mathrm{H}_{0}\right)$ is that a unit root is present and $\theta=0$.

The results indicate a significant $(p=0.001)$ DFT statistic equal to -3.375 . Assuming the series has a constant but no trend, for our 121 cases, -3.375 is below the 5\% DFT critical values of $-2.891 /-2.873$ (samples of 100 or 250 respectively). So the null hypothesis of a unit root is rejected and the series appears stationary enough without differencing for an initial analysis. However, if we impute a trend (as Fig.10 portends), then the relevant DFT critical values increases to -3.45/-3.43 and we can no longer reject unit root hypothesis and so series statistics are unreliable without differencing (Koop 2013). In short, the DFT diagnostics were equivocal and the pool series is, at best, weakly stationary.

Notwithstanding the need for cautious interpretation, the study input this untransformed series (3c) into SPSS Time Series Modeller to generate an Autoregressive Integrated Moving Average (ARIMA) model (3c) with a Stationary R-squared of 0.421 , suggesting that the model improves fit by $42 \%$ compared to a simple mean for the stationary part of the series (see Table 5).

Table 5: Diagnostic statistics for untransformed pools construction time series ARIMA model (3c)

\begin{tabular}{|c|c|c|c|c|c|}
\hline \multicolumn{2}{|c|}{ Normalized BIC } & $\begin{array}{c}\text { Stationary R- } \\
\text { squared }\end{array}$ & RMSE & MAPE & Ljung-Box Q(18) \\
\hline \multicolumn{2}{|c|}{6.324} & .421 & 22.247 & 85.772 & $28.173(0.021)$ \\
\hline \multicolumn{2}{|c|}{ Estimate } & & s.e. & $\mathrm{t}$ & Sig. \\
\hline$A R$ & $\operatorname{Lag} 1$ & -.273 & .090 & -3.015 & .003 \\
\hline \multirow[t]{2}{*}{ MA } & Lag 5 & -.176 & .079 & -2.230 & .028 \\
\hline & $\operatorname{Lag} 10$ & -.611 & .083 & -7.350 & .000 \\
\hline
\end{tabular}

The Bayesian Information Criterion (BIC) is a model selection criterion that increases with the number of cases, unexplained error variance and IVs but the study did not field any alternative untransformed candidates. The study loss functions indicates differences between model outputs and actual values. The Root Mean Square Error (RMSE) of 22.247 indicates the standard deviation of the unexplained variance over the series was less than 23 pools (out of 116 years of construction data). Mean Absolute Percent Error (MAPE) indicates, in general an $>85 \%$ divergence between forecast and actual results. The Ljung-Box $Q(L B Q)$ is a portmanteau test of overall randomness of residual errors (white noise 
process). The $p$-value of 0.021 provides some evidence $(p=0.05<0.1)$ of a residual pattern. Serial autocorrelation means standard errors are underestimated and hypothesis tests unreliable. With these caveats in mind, significant autocorrelation lags were at 1, 5 and 10 years. Running ARIMA (3c), forecasts construction of 30 pools 2025 but with prudent margin of error (see Fig 11).

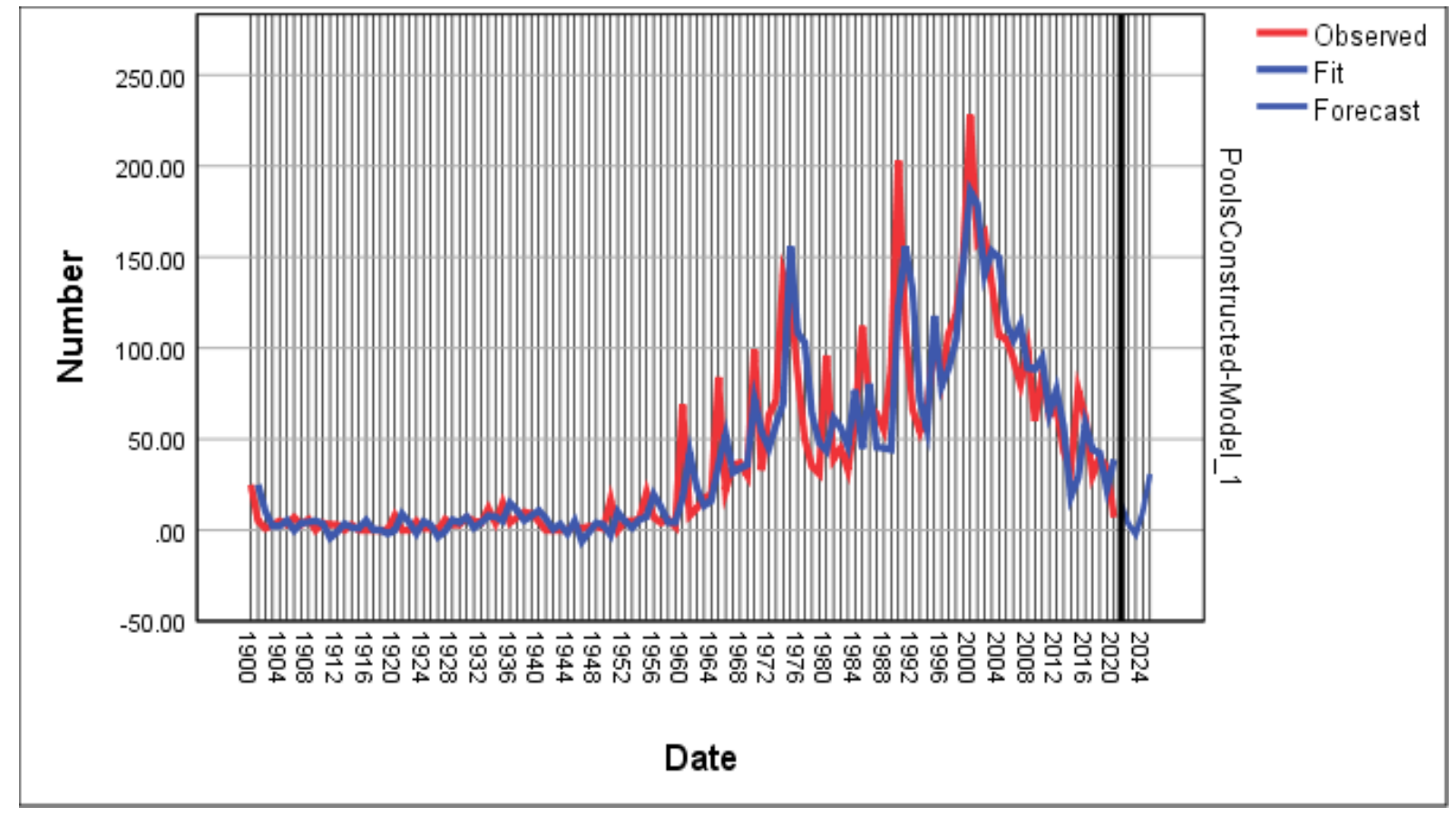

Figure 11: Time series model (3c) on untransformed pool construction data, forecast to 2025

As discussed, the borderline DFT and LBT diagnostics for the untransformed 3c series flags spurious regression risk (misleading coefficients and statistics). To mitigate, the study transformed the data and ran an autoregressive distributed lag model (3d) and an error correction model (3e) using first differences of DV and IVs (Koop 2013) with stronger stationary credentials. For 3d, the modelling assumed that changes in pool construction (DV) are driven by previous construction activity, previous fluctuations in it and a combination of other current and lagged IVs (real GDP and population levels or changes).

$\Delta \mathrm{PC}=\mathrm{PCt}-1, \Delta \mathrm{PCt}-1, \mathrm{GDP}, \Delta \mathrm{GDP}, \Delta \mathrm{GDPt}-1, \mathrm{Pop}+\Delta \mathrm{P}+\Delta \mathrm{Pt}-1$ (3d) 
Table 6: Transformed pool construction ADL modelling (3d) diagnostic statistics

\begin{tabular}{l|r|r|r|r}
\hline Model & R & R Square & Adjusted R Square & Std. Error of the Estimate \\
\hline $3 d$ & $.489^{\mathrm{a}}$ & .239 & .184 & 26.243 \\
\hline
\end{tabular}

Predictors: (Constant), PC Lagged, $\triangle \mathrm{PCt}-1, \mathrm{GDP}, \Delta \mathrm{GDP}, \Delta \mathrm{GDPt}-1$, Pop, $\Delta \mathrm{P}, \Delta \mathrm{Pt}-1$

\begin{tabular}{|c|c|c|c|c|c|c|}
\hline \multicolumn{2}{|c|}{ Model } & \multirow{2}{*}{$\begin{array}{r}\text { Sum of Squares } \\
23830.343\end{array}$} & \multirow{2}{*}{ df } & \multirow{2}{*}{$\begin{array}{l}\text { Mean Square } \\
2978.793\end{array}$} & \multirow{2}{*}{$\frac{F}{4.325}$} & \multirow{2}{*}{$\begin{array}{l}\text { Sig. } \\
.000^{\mathrm{b}}\end{array}$} \\
\hline $3 d$ & Regression & & & & & \\
\hline & Residual & 75755.624 & 110 & 688.687 & & \\
\hline & Total & 99585.966 & 118 & & & \\
\hline & Ljung-Box Q(18) & 28.173 & .021 & & & \\
\hline & & \multicolumn{2}{|c|}{ Unstandardized Coefficients } & Standardized Coefficients & & \\
\hline \multicolumn{2}{|c|}{ Model } & B & Std. Error & Beta & $\mathrm{t}$ & Sig. \\
\hline \multirow[t]{9}{*}{$3 d$} & (Constant) & -5.192 & 38.263 & & -.136 & .892 \\
\hline & PC_Lagged & -.282 & .085 & -.472 & -3.329 & .001 \\
\hline & $\Delta \mathrm{PCt}-1$ & -.179 & .097 & -.179 & -1.837 & .069 \\
\hline & Pop & .327 & 1.053 & .075 & .310 & .757 \\
\hline & $\Delta \mathrm{P}$ & -7.170 & 22.158 & -.036 & -.324 & .747 \\
\hline & $\Delta \mathrm{Pt}-1$ & -23.089 & 21.732 & -.114 & -1.062 & .290 \\
\hline & GDP & $6.065 \mathrm{E}-6$ & .000 & .099 & .345 & .731 \\
\hline & $\triangle G D P$ & .000 & .000 & -.072 & -.653 & .515 \\
\hline & $\triangle \mathrm{GDPt}-1$ & .001 & .000 & .316 & 2.884 & .005 \\
\hline
\end{tabular}

The coefficient on $P C \_$Lagged $(\theta)$ is $<0$, suggesting model stability (Koop, 2013, 172). There is strong evidence $(p=0.001)$ that lagged pool construction has a significant influence on the change in pool construction which confirmed the stationarity of the transformed series ( $\theta$ is not 0 so $\varphi$ in $3 c$ is $<1$ ). Fig.12 lends intuitive support to series stationarity. The evidence for lagged changes in pool construction was only borderline $(p=0.069)$. However, for lagged alterations in economic activity $(\triangle G D P t-1)$ the evidence is strong $(p=0.005)$ that upswings influence subsequent pool construction. 


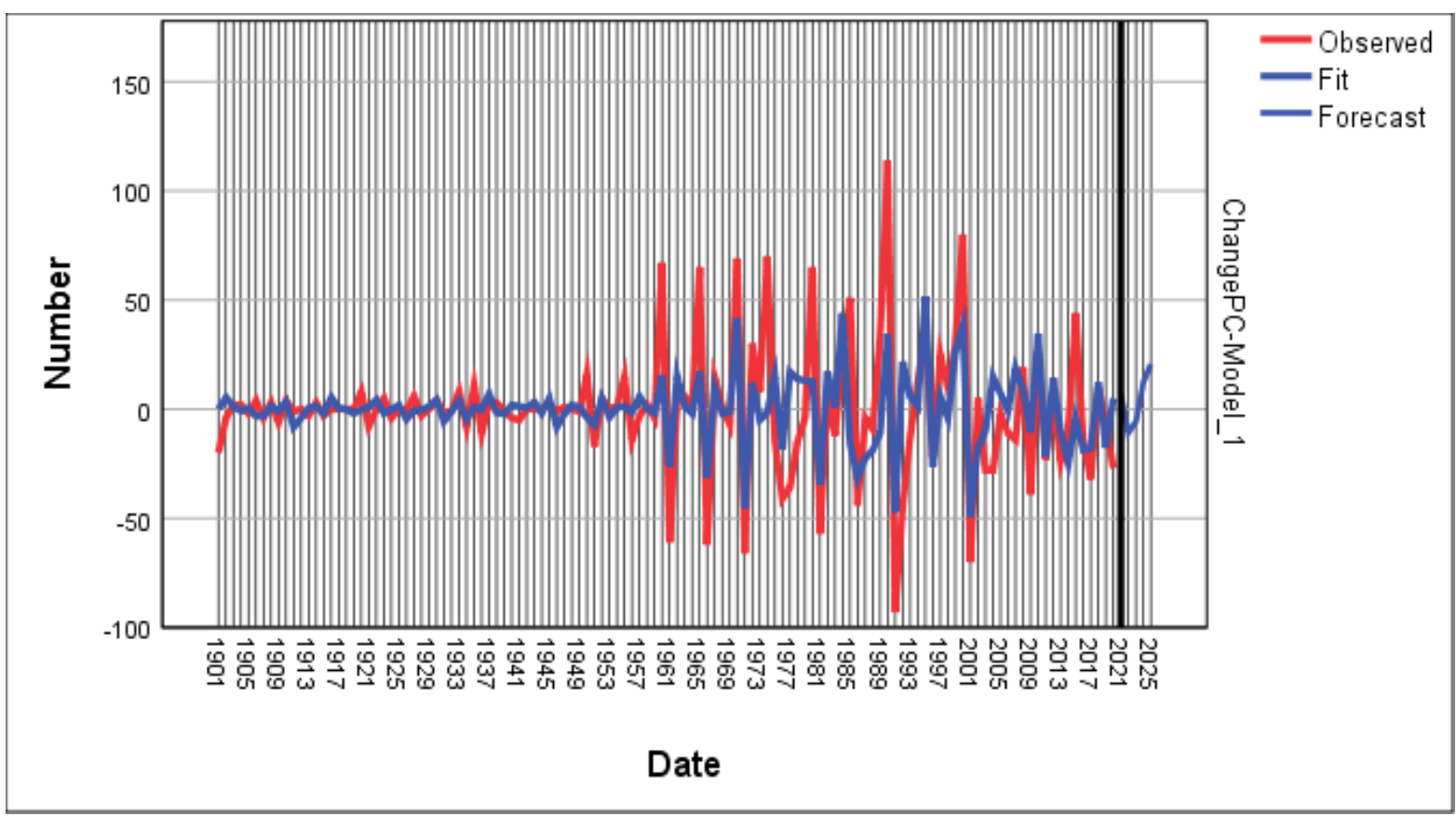

Figure 12: Forecasting result generated by transformed pool construction ADL modelling of time series (3d)

The study also ran an Error Correction Model (ECM) (3e) that used previous departures from fitted estimates to adjust pool construction. The diagnostics in Table 7 suggest there is strong evidence $(p=0.003)$ of error correction (reversion to mean) but lagged changes in GDP only have a borderline influence on construction $(p=0.075)$, naturally only detectable through its standardised coefficient so if GDP grew by one SD then, the following year, pool construction would rise by around $15 \%$. 
Table 7: Error correction model $\Delta \mathrm{PC}=$ (Constant), et-1, $\Delta \mathrm{GDPt}-1, \Delta \mathrm{Pt}-1, \Delta \mathrm{PCt}-1$ (3e)

\begin{tabular}{|c|c|c|c|c|c|}
\hline $\mathrm{R}$ & R Square & Adjusted R Square & Std. Error of the Estimate & Durbin-Watson & \\
\hline $.432^{\mathrm{a}}$ & .187 & .158 & 26.653 & 2.018 & \\
\hline $3 e$ & Sum of Squares & df & Mean Square & $\mathrm{F}$ & Sig. \\
\hline Regression & 18604.497 & 4 & 4651.124 & 6.548 & $.000^{b}$ \\
\hline Residual & 80981.469 & 114 & 710.364 & & \\
\hline \multirow[t]{2}{*}{ Total } & 99585.966 & 118 & & & \\
\hline & $\mathrm{B}$ & Std. Error & Beta & $\mathrm{t}$ & Sig. \\
\hline (Constant) & -.978 & 4.741 & & -.206 & .837 \\
\hline$\triangle \mathrm{PCt}-1$ & .270 & .209 & .270 & 1.292 & .199 \\
\hline$\Delta \mathrm{Pt}-1$ & -10.412 & 17.234 & -.051 & -.604 & .547 \\
\hline$\triangle \mathrm{GDPt}-1$ & .000 & .000 & .153 & 1.794 & .075 \\
\hline et-1 & -.688 & .228 & -.628 & -3.013 & .003 \\
\hline
\end{tabular}

A limitation of ECM modelling was that Engle Granger cointegration tests were not conducted to mitigate against spurious regression (Koop 2013). Durbin-Watson statistic is 2.018 within acceptable 1.5 and 2.5 limits, intimated that residuals were uncorrelated and reasonable DV predictors. However, PP plots and scatterplots (not illustrated) showed that residuals 'funnelled' and or fell systematically as $\triangle P C$ increases. This flags some modelling issues, probably related to the increased dispersion of construction activity over time, as indicated by the Fig. 13.scatterpolot.

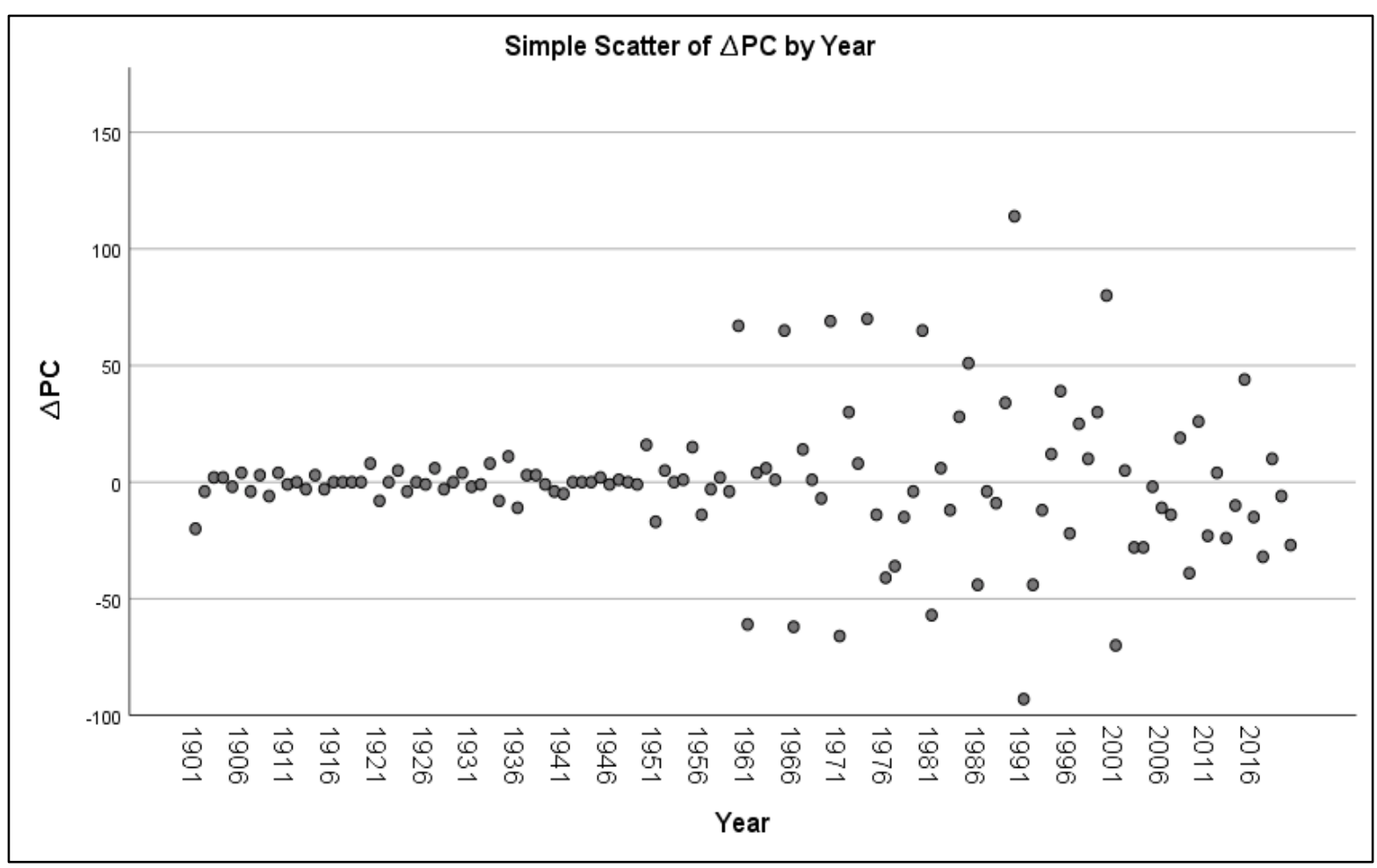

Figure 13: Scatterplot of revised ECM, illustrating series stationarity but temporal variance dispersion 


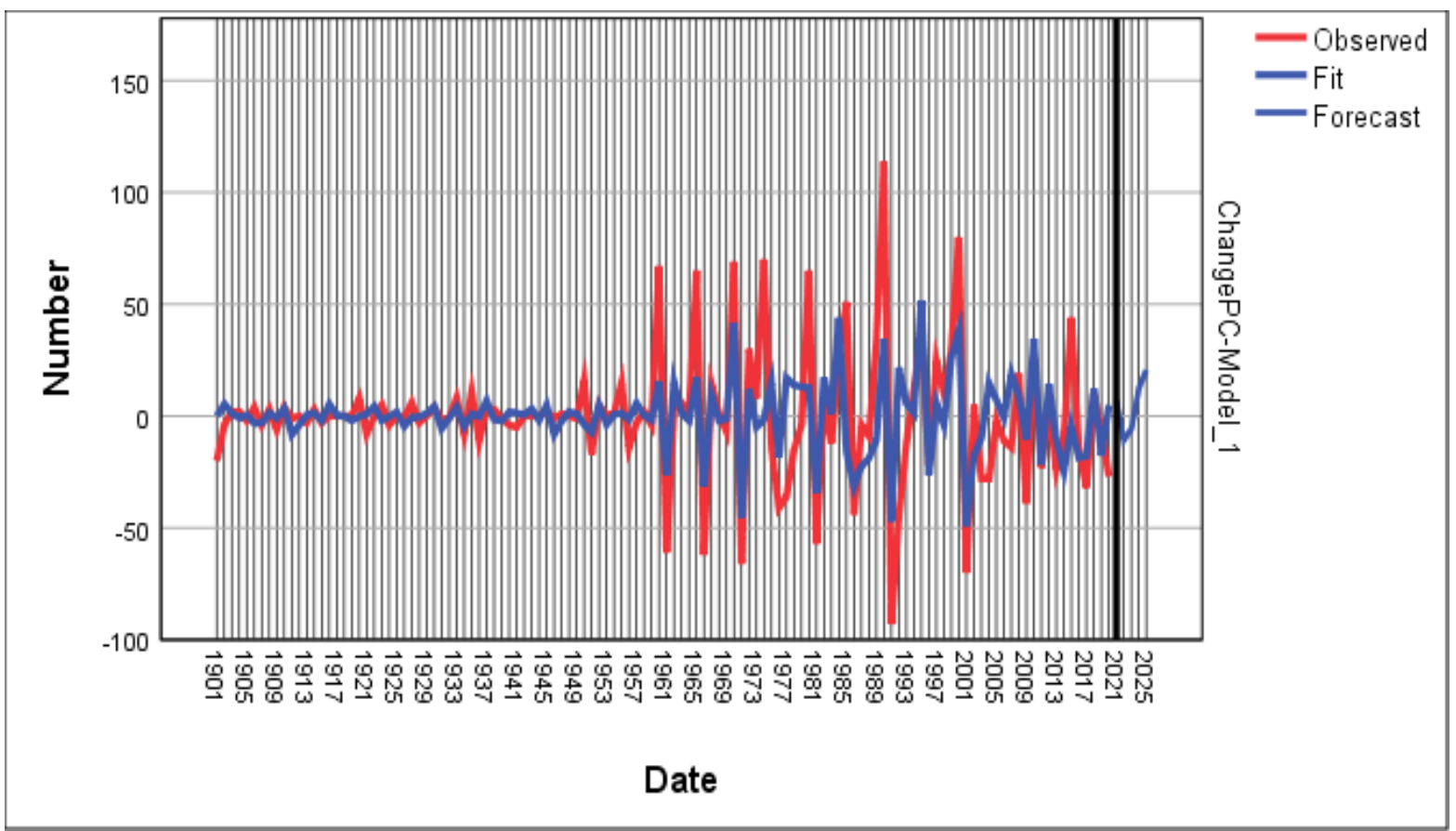

Figure 14: ECM modelling (3e), illustrating indicative need to ramp up bathing facilities construction to return to equilibrium

All three times series models project an increase in pool construction which lends support to $\mathrm{H} 2_{\mathrm{A}}$ of an increased pool construction need. For RQ2 then, current levels of swimming pool construction appear inadequate.

\section{Nomothetic conclusion}

The cross-sectional statistical analysis (3a) refuted the null hypothesis that pool density has no influence on deaths $\left(\mathrm{H}_{0}: \beta 5=0\right)$. The study thereby, answered its first question in the affirmative that the geospatial distribution of swimming facilities is associated with health. Given the acknowledged limitations of the pools data, the results are only preliminary. For the times series modelling, recent construction fluctuations and the time series forecasts (3c-e) are indicative of policy flux and lend qualified support to a moderate and targeted increase in pool construction, subject to appropriate evaluation and planning approval. However, statistical results need careful consideration. The Vietnamese War provides perhaps the most telling example of 'data dictatorship' that spawned misguided policy. Notoriously, Robert McNamara, America's secretary of defence (1961 - 1968), infamously relied on body bag counts and other statistical metrics to evaluate the operational 'performance' of US forces. He neither considered metric gaming by generals nor the patriotic ardour of his Vietnamese enemies (Cukier \& Mayer-Schönberger, 2013). To mitigate the risk of statistical myopia and enrich its policy insights for RQ3, the study also considered some idiosyncratic swimming pool case studies. 


\section{Idiographic case studies}

Following traditions of inter and transdisciplinary research at different levels of abstraction (Baumgärtner et al., 2008), the study identified three idiosyncratic bathing facilities for investigation. A formal case study survey to bridge the nomothetic-idiographic divide was not attempted (see e.g. Larsson, 1993) but the case studies triangulated evidence and generated some useful preliminary insights. The three cases included English metropolitan (Bromley) and regional (Cirencester) sites and an overseas facility (Ludenscheid, Germany). The comparative case study research integrated visits, recollections, online information or requested documentation to sketch geographical context and pool facilities development or management issues.

\section{Bromley}

Bromley is a prosperous South East London borough with 331,002 residents (ONS, 2018) and one of the highest UK retail spends. In 2017, its gross disposable household income (GDHI) per head exceeded the national average by $45.2 \%$. In that year, GDHI income in the Borough grew at $2.4 \%$, compared to the UK's lacklustre 1\% (ONS, 2020). Bromley's economy is comparable to that of Reading and is fuelled by easy rail access to London (Victoria and Charring Cross) or the continent. 'Old money' is crystallised in pockets of residential housing wealth (e.g. Chislehurst and Keston) but much 'new money' is incubated in the Borough's substantive office $\left(335,000 \mathrm{~m}^{2}\right)$ or retail spaces (Ramidus Consulting, 2017). 41\% of local jobs are in financial services (e.g. selling insurance), although their usefulness and pandemic resilience remains uncertain. Under the commercial froth, the Borough's record in the public health sphere is mixed. Although, the second stated objective of its Core Strategy is 'a health infrastructure to support people in living longer, healthier lives' (Bromley 2020, 2.02), preliminary analysis suggests pool scarcity. The Council's web site (04/04/2020) listed 7 public bathing facilities which implies 47,286 people share each pool (see Caracalla's baths above for indicative capacity comparison). The discrepancy between the 36 (public and private) pools logged on SE (2020) database and the seven accessible facilities illuminates pool data quality issues noted earlier in data section and subsequently acknowledged in the study's limitations.

In 1925, Southlands Road Lido opened on Bromley Common, at that time a relatively sparsely built-on precinct. For decades, the open air pool provided a healthy outlet for children in London's burgeoning south eastern suburb (Ideal Homes, 2020). In June 1983, the Conservative council decided to close the lido and sold the land to Holme's Place (HP) private health club (Bromley 1983). Subsequently, the ownership structure of HP went through various permutations, involving the Virgin group, presumably linked to tax or other vagaries of global capitalism. Planning records are Spartan and consider mainly car parking or vehicular access provision (ibid.). Curiously, SE database record of this facility (Site ID: 1000344) fails to reveal the site's heritage, community health contribution or public 
asset origin and only list it as a Virgin Active Club. The stealthy takeover of Southlands Road Lido by a Virgin subsidiary looks and feels like accumulation by dispossession (Harvey 2005, 2007; Das, 2017). Presumably, Harvey would consider HP/Virgin group a predatory privatisation vehicles that leverages private equity to expropriate public assets. Instead of a public sporting milieu for needy children, the lido premises now gratifies the narcissistic impulses of a global elite so they can 'live longer, happier and more balanced lives' (HP website, 2020). In relation RQ3 on policy learning, this case study (4a) accentuates rather than subdues pool phronesis concerns. Having considered a metropolitan bathing case, the study turned its attention to an English regional one 90 miles west of the capital.

\section{Cirencester}

Administratively, Cirencester sits within the Cotswold District Council (CDC) - a local government tier. In 49AD, Publius Scapula (AD 15 - 52) constructed a fort on a limestone outcrop for two quingenary alae ( 1000 auxiliary horsemen) to defend the Fosse Way from Caratacus (AD 15-54) and oversee the Dobunni tribesmen at Bagendon, three miles north (RCHME, 1976). Subsequently, probably for both logistical and cultural reasons, the Romans built Corinium on the floodplain between Thames tributaries (Daglingworth Brook and the Churn). Generally, the market town thrived except during the Civil War (1642-1651) when loyalties were sharply divided. Nowadays, the settlement's population is 20,780 (OCSI, 2018) but $17 \%$ have a limiting long-term illness (ibid.).

Although, CDC notional pool availability is above the English average (1.68 vs. 1.07 per 10,000 residents), as with Bromley, many are private facilities. Sports England (2020) data lists 10 CDC pools (as detailed in Table 8). In fact, in CDC, only 3 pools seem accessible to the general public (47\% of CDC total bathing space). 
Table 8: Bathing facilities within Cotswold District Council, indicating access restrictions

\begin{tabular}{l|l|l|l|l}
\hline Site Name & Year Built & Area & Ownership Type & Public Access? \\
\hline Bourton Leisure Centre & 2003 & 225 & Commercial Management & Y \\
\hline Calcot Manor Spa & 2003 & 112 & Commercial & N \\
\hline Cirencester Leisure Centre & 2006 & 325 & Commercial Management & Y \\
\hline Cirencester Open Air Pool & 1869 & 378 & Trust & Y \\
\hline Chipping Campden & 1996 & 162 & Commercial Management & Y \\
\hline Fire Service College Leisure Club & 1977 & 225 & Commercial & N \\
\hline National Star College & 2000 & 325 & Sixth Form Centre & N \\
\hline Northleach Primary School & 1868 & 101.5 & School & N \\
\hline Rendcomb College & 1960 & 250 & Independent School & N \\
\hline Westonbirt Leisure Centre & 2005 & 210 & Independent School & N \\
\hline TOTAL (available to pubic) & & 2313.5 & & $47.1 \%$ \\
\hline
\end{tabular}

Currently, the Cotswold Leisure Centre in Cirencester is operated by Everyone Active, an entity owned by Sports and Leisure Management Ltd (SLM). SLM is a private limited Company registered in 1987 based in Hinckley, Leicestershire which, in turn is controlled by Castle View Ventures (CVV). SLM manages over 190 UK centres across the UK in partnership with over 60 local authorities. Over its 2018-19 financial year, SLM turnover grew by almost 20\% with profits up by $23.3 \%$ (Companies House 2020). In the year to 2019 , SLM return on capital employed (ROCE) ${ }^{5}$ was $43.2 \%$ and its cash grew from $£ 35 \mathrm{~m}$ to over $£ 41 \mathrm{~m}$. In 2019 , it paid dividends of $£ 10 \mathrm{~m}$, presumably to CVV and its three principle Scottish-based investors. The limited due diligence suggests unprecedented profits accruing to a small group of privileged investors and seems to accord with a narrative of dispossession.

\section{Ludenscheid}

Lüdenscheid is a regional German settlement in North Rhine-Westphalia south of Dortmund with a population of around 70,000. It is located on a watershed between two Ruhr tributaries. Originally a member of the Hanseatic League, its economy was founded on metal ore mining and component manufacturing. In fact, in 1898 the aluminium framework of the first Zeppelin airship was built in Lüdenscheid. As a provincial town, its industrial base is more diversified and its population 3.3X larger

\footnotetext{
${ }^{5}$ Defined as Operating Profit in 2019/ (Total assets - Current liabilities in 2018)
} 
than Cirencester's. The Familienbad Nattenberg Lüdenscheid (FNL) is a $25 \mathrm{~m}$ indoor lap poor with $70 \mathrm{~m}$ long slide, conservatory, and outdoor diving and leisure pools. Its translucent foil roof and sliding side walls flood rooms with natural light and give unrestricted views over and summertime access to greenery (see Fig. 15). Hygienically, ventilation and natural lighting is desirable.

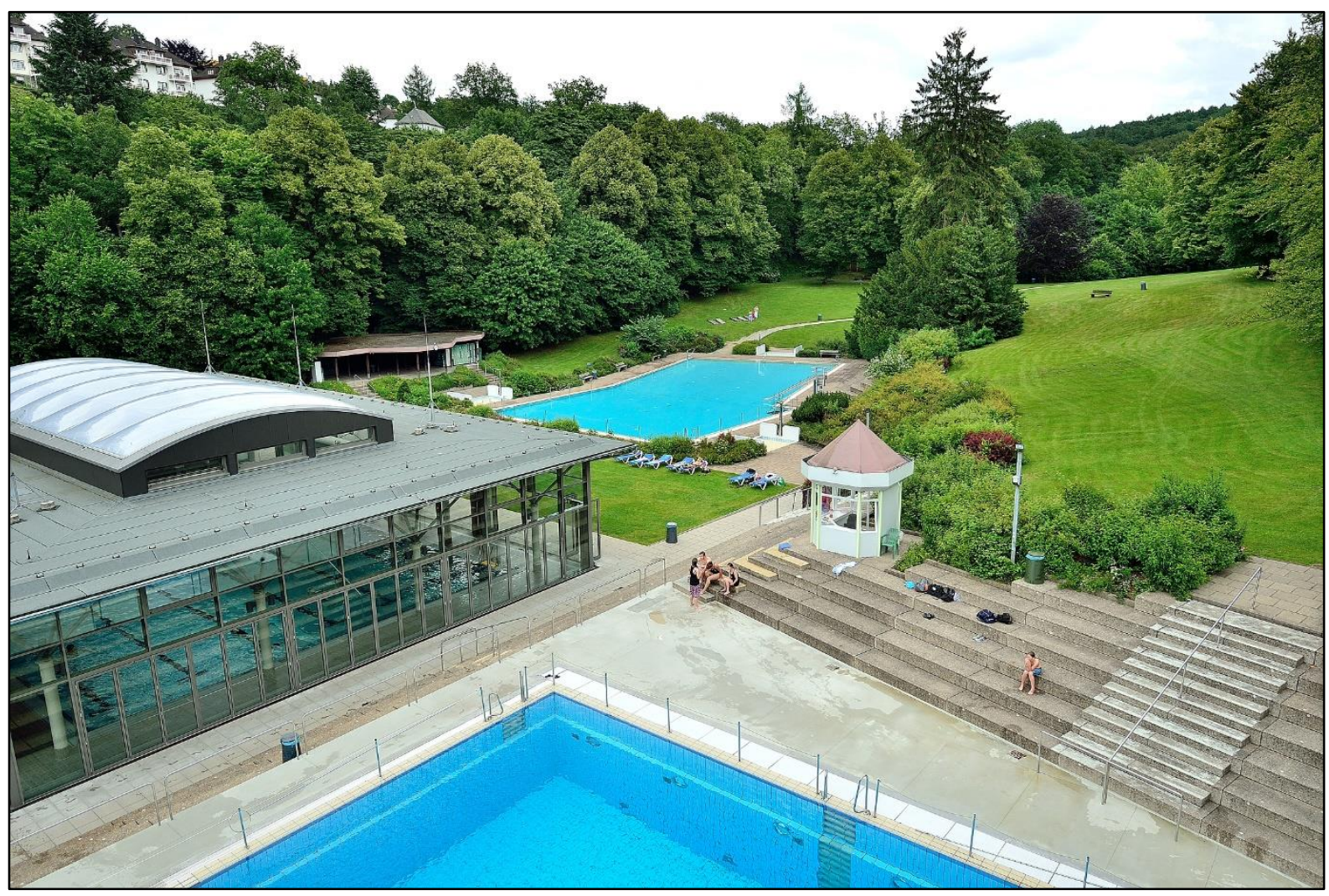

Figure 15: Familienbad Nattenberg Lüdenscheid illustrating quality local bathing facilities (Source: Franz van Stephoudt GmbH \& Co. KG Bauunternehmung).

FNL illustrates a well-designed bathing facility, fit for community health purpose in a regional German settlement.

\section{Case study conclusion}

The idiographic case studies illustrate bathing facility idiosyncratic complexity in diverse geographical settings but seem to confirm a narrative of relative English underinvestment, although it is acknowledged that the study is preliminary and further cases would strengthen assurance. The exemplary German facility contrasted with mismatch between English health rhetoric and facilities liquidation (Bromley) or outsourcing and semi-privatisation (Cotswolds). Arguably, in the Cotswolds, Table 8 hints at Dickensian health exclusion with less than a half CDC's bathing resources apparently actually accessible to the public. The contrast with ancient Rome seems marked. Marcus Aurelius intimates that he, albeit reluctantly, rubbed shoulders with the hoi palloi (oi ro $\lambda \lambda$ oí). Notwithstanding 
their somewhat anecdotal selection and limited coverage, the three case studies bring interpretivist insights that seem to reinforce statistical concerns about English health phronesis.

\section{Limitations}

The study had a number of limitations that future health and sports facilities research could address. For the literature review (2), the study did not incorporate modified Downs \& Black (1998) criteria to restrict diversity and perhaps enable a meta-analysis. Another study limitation concerned the heterogeneous pool data with diverse facilities in disparate states of repair and varied access or ownership structures (3b). Future pool phronesis research needs to, first, audit the geospatial integrity of pool data for locales, partnerships and local delivery pilots and, subsequently, tighten pool quality criteria to screen out small or private facilities. Better, rather than communal cross-sectional analysis of excess deaths, future research should involve individual-level personal panel data analysis (Sloggett \& Joshi 1994). For time series (3c-e), an independent expert audit of modelling would be useful. The study's three idiographic case studies limited generalisability (4a-c). Improvements involve expanding sampling, replacing anecdotal with formal sampling or tightening thematic analysis to improve trustworthiness (Nowell et al., 2017).

\section{Conclusion}

The study investigated the impact of pools on health and their construction history in England. It used an interdisciplinary mixed methods and phronetic research approach with four main lines of inquiry (five phases including synthesis with two nested empirical stages). First, the research identified the health and bathing infrastructure issue and outlined the English chronic obesity epidemic, underlying the current COVID-19 epidemiological one (1). A contextual and structured literature review (2) expounded the pools historical background and provided a salutary reminder of Rome's aquatic achievements, notwithstanding its slave economy (2a). The structured literature review confirmed the intuition that sports facilities are associated with public health (2b). Ministerial rhetoric aside, in comparison with the situation in antiquity, public bathing provision in England seems inadequate for

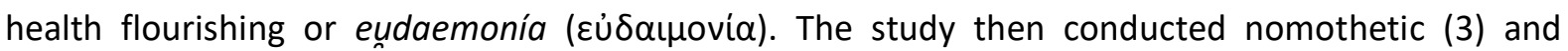
idiosyncratic (4) primary research to investigate three questions. First, a cross-sectional analysis found that deprivation, obesity but also swimming facilities density significantly influenced mortality in English locales ( $3 a \& b)$. Subsequent time series statistical analysis of 120 years of English swimming pool construction activity from 1900 found infrastructure provision increasingly erratic and inadequate for health needs (3c-e). Finally, for insight and policy learning, the study enriched its 
nomothetic enquiry lines with idiosyncratic, interpretive research involving three swimming pool case studies (4). The case studies illustrated complexity and contrasted unsatisfactory English public asset management with, seemingly, more enlightened overseas provision. Arguably, the Bromley and Cirencester examples suggest, if not 'sabotage' or 'legalized seizure' by errant firms, then 'manoeuvres of deviation' or 'pecuniary operations' (Veblen, 1919 pp. 34-36). At the very least it seems, council

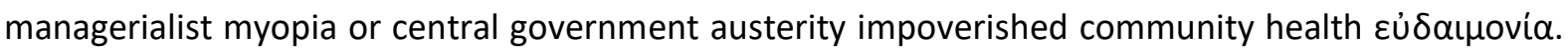
While the initial study withholds scientific judgement on 'accumulation by dispossession' its findings suggest preventative public health ecosystem weakness or deficiencies in planning фpóvnoıs (phronesis).

Notwithstanding its limitations, the preliminary analysis feeds into a growing consensus for dialogue and reflection for socio-economic and health system re-calibration. To help resolve complex health policy issues Funtowicz and Ravetz (1991) advocate 'post-normal science'. For Munda (2004, 2008) Social Multi Criteria Evaluation (SMCE) provides a useful framework to structure and analyse multidimensional public health issues. SMCE is effectively a structured phronetic or praxis-based approach that helps navigate contentious, high stakes or urgent problems. The COVID crisis illustrates how phronesis could provide a platform for scientific, social and economic policy deliberations (Petersén and Olsson, 2015). For public health, social, ecological or urban problems in a complex doughnut economy (Raworth, 2017), phronesis can generate ethical and workable solutions that overcome paradigm incommensurability, asymmetries of power, social and cultural constraints. Eventual fruits of multi-dimensional political engagement to 'level up' could include green infrastructure (cycle ways, trams etc.) or bathing and other appropriate sports facilities. As a quid pro quo for subsidies, funding models may need to temper short-term and unevenly-distributed commercial proclivities against considerations of spatial justice and community preventative health. 


\section{Acknowledgements}

- Sports England for online access to their Active Places Power database https://www.sportengland.org/

- Franz van Stephoudt GmbH \& Co. KG Bauunternehmung for Figure 15 photo of Familienbad Nattenberg Lüdenscheid http://www.stephoudt.de/

- Associate Professor Alun Owen and Dr Jia Shao at Sigma, Coventry University http://sigma.coventry.ac.uk/

\section{Acronyms}

\begin{tabular}{l|l|l|l}
\hline ADL & Autoregressive distributed lag & HP & Holme's Place Private Health Clubs \\
\hline AHAH & Access To Healthy Assets And Hazards & IV & Independent Variables \\
\hline APP & Active Places Power (Sports England) & LGA & Local Government Area \\
\hline ARIMA & Auto Regressive Integrated Moving & MAPE & Mean Absolute Percent Error \\
\hline BIC & Bayesian Information Criterion & OCSI & Oxford Consultants For Social \\
\hline BLUE & Best Linear Unbiased Estimator & ONS & Office For National Statistics \\
\hline BoE & Bank Of England & PCA & Principal Components Analysis \\
\hline BMI & Body Mass Index & RMSE & The Root Mean Square Error \\
\hline CDC & Cotswold District Council & ROCE & Return On Capital Employed \\
\hline CDRC & Consumer Data Research Centre & SD & Standard Deviation \\
\hline CVV & Castle View Ventures & SE & Sports England \\
\hline DFT & Dicky Fuller Test & S.e. & Standard Error \\
\hline DV & Dependent Variable & SW & Shapiro-Wilk Test \\
\hline ECM & Error Correction Model & SLM & Sports And Leisure Management Ltd. \\
\hline GDHI & Gross Disposable Household Income & VIF & Variance Inflation Factors \\
\hline FNL & Familienbad Nattenberg Lüdenscheid & & \\
\hline & & & \\
\hline
\end{tabular}




\section{Bibliography}

Andree, R. (1886) Allgemeiner Historischer Handatlas, Droysen. G. (Ed), Plate 12, http://www.maproom.org/00/08/present.php?m=0012

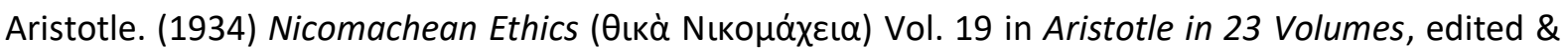
translated by H. Rackham. Cambridge, MA, Harvard University Press. London, William Heinemann Ltd.

Aurelius, M. ( 167AD) Meditations VIII.XXIV in Loeb Classic edition C. Haines (Ed. \& Trans). doi: 10.4159/DLCL.marcus_aurelius-meditations.1916

https://www.loebclassics.com/view/marcus aureliusmeditations/1916/pb LCL058.209.xml?rskey=J3jWDI\&result=1

Broadberry, S., Campbell, B., Klein, A., Overton M., Van Leeuwen, B. (2015), British Economic Growth, 1270-1870. Cambridge, University Press. http://www.cambridge.org/gb/academic/subjects/history/economic-history/britisheconomic-growth-12701870?format=PB

Baumgärtner, S., Becker, C., Frank, K., Müller, B. \& Quaas, M. (2008). Relating the philosophy and practice of ecological economics: The role of concepts, models, and case studies in inter- and transdisciplinary sustainability. Ecological Economics, 67(3), 384-393. doi: 10.1016/j.ecolecon.2008.07.018

Bromley (1983). Planning - Application Summary 83/00234/FUL, Received 28/01/1983, amended 16/05/1983, granted 17/06/1983. Lido, Southlands Road Bromley BR2 9RB alterations to swimming pool to provide leisure centre with restaurant including car parking | Holmes Place Baths Road Bromley BR2 9RB.

Bromley (2020) Corse strategy issues consultation. https://bromleyconsult.objective.co.uk/portal/cs/csissues?pointld=s1302517290957\#section$\underline{\mathbf{s} 1302517290957}$

Caird, J. Kavanagh J., O'Mara-Eves A. et al. (2014). Does being overweight impede academic attainment? A systematic review. Health Education Journal, 2014(73), 497-521.

Carcopino, J. (1940). Daily life in ancient Rome (trans. Lorimer, E.). New Haven: Yale University Press. La vie quotidienne à Rome à l'apogée de l'Empire, Paris, Hachette, 1939, 348

Claridge, A. (1998). Rome: An Oxford Archaeological Guide, First, Oxford, Oxford University Press. 
CDRC (2020). Consumer Data Research Centre. Liverpool University. https://data.cdrc.ac.uk/dataset/ahah2

Cukier, K. \& Mayer-Schönberger V. (2013). The Dictatorship of data: Robert McNamara epitomizes the hyper-rational executive led astray by numbers. MIT Technology Review May 31, 2013 https://www.technologyreview.com/2013/05/31/178263/the-dictatorship-of-data/ $(22 / 04 / 20)$.

Das, R. (2017). David Harvey's theory of accumulation by dispossession. World Review of Political Economy, 8(4), 590-616.

Davis, D. (2015). A Gramscian analysis of Roman bathing in the provinces. University of South Florida Graduate Theses and Dissertations. https://scholarcommons.usf.edu/etd/5465

Deem, R. (2000). New managerialism and the management of UK universities. Economic and Social Research Council.

DeLaine, J. (1988). Recent research on Roman baths. Journal of Roman Archaeology, 1, 11-32.

DeLaine, J. (1997). The Baths of Caracalla: a study in the design, construction, and economics of largescale building projects in imperial Rome. Journal of Roman Archaeology. Series Number 25.

Deming D. (2020). The aqueducts and water supply of Ancient Rome. Ground water, 58(1), 152-161. doi.org/10.1111/gwat.12958

Downs S., Black N. (1998). The feasibility of creating a checklist for the assessment of the methodological quality both of randomised and non-randomised studies of health care interventions. Journal of Epidemiology \& Community Health, 52 (6), 377-384.

Eime, R., Young, J., Harvey, J., Charity, M., Payne, W. (2013). A systematic review of the psychological and social benefits of participation in sport for adults: informing development of a conceptual model of health through sport. International Journal of Behavioural Nutrition and Physical Activity, 10.

Eime, R., Harvey, J., Charity, M., Casey, M., Westerbeek, H., \& Payne, W. (2017). The relationship of sport participation to provision of sports facilities and socioeconomic status: a geographical analysis. Australian and New Zealand Journal of Public Health, 41(3), 248-255.

Fagan, G. (1999). Bathing in public in the Roman world. Ann Arbor, Michigan: University of Michigan Press. 
Fisher, K., Li, F., Michael, Y., \& Cleveland, M. (2004). Neighbourhood-level influences on physical activity among older adults: a multilevel analysis. Journal of aging and physical activity, 12(1), 45-63.

Fletcher, B. (1921). Plan of the Baths of Caracalla. A History of Architecture on the Comparative Method. $6^{\text {th }}$ edition. p. 105. New York, Charles Scribner's Sons.

Funtowicz, S., Ravetz, J. (1991). A new scientific methodology for global environmental issues. In Ecological Economics, the science and management of sustainability, 137-152 (Ed. R Costanza). New York, Columbia Press.

Gagliano, A. Liuzzo, M., Margani, G. and Pettinato, W. (2017). Thermo-hygrometric behaviour of Roman thermal buildings: the "Indirizzo" Baths of Catania (Sicily). Energy and Buildings, 138 (1) 704-715. doi: 10.1016/j.enbuild.2016.12.011.

Giampaoli,S. \& Spica, V. (2014). Health and safety in recreational waters. Bulletin of the World Health Organization, Feb 2014, Vol.92 (2), p.79. Volume 2: Swimming pools and similar environments. Geneva: World Health Organization.

Gibson, S. (2008). Sugar-sweetened soft drinks and obesity: a systematic review of the evidence from observational studies and interventions. Nutrition Research Reviews, 21(2), 134-147.

Global Health Observatory (2020). Prevalence of obesity among adults, BMI >= 30 (age-standardized estimate). World Health Organisation, available at: https://www.who.int/data/gho/data/indicators/indicator-details/GHO/prevalence-of-obesityamong-adults-bmi-=-30-(age-standardized-estimate)-(-)

Green, M., Daras, K., Davies, A., Barr, B. \& Singleton, A. (2016). Developing an openly accessible multidimensional small area index of Access to Healthy Assets and Hazards for Great Britain, Health \& Place, 54(November 2018), 11-19. doi. 10.1016/j.healthplace.2018.08.019.

Harvey, D. (2005). A brief History of neoliberalism. Oxford, Oxford University Press.

Harvey, D. (2007). Neoliberalism as creative destruction. The Annals of the American Academy of Political and Social Science, 610, 22-44.

Heesch, K.C., Giles-Corti, B. \& Turrell, G. (2014). Cycling for transport and recreation: Associations with socio-economic position, environmental perceptions, and psychological disposition. Preventive medicine, 63, 29-35. 
HM Government (2015). Sporting future - a new strategy for an active nation. London, Department for Digital, Culture, Media \& Sport.

Ideal Homes. (2020). A history of South-East London suburbs. http://www.idealhomes.org.uk/bromley/assets/galleries/bromley-common/southlands-lido

Jackson, S. \& Steptoe, A. (2017). Association between perceived weight discrimination and physical activity: a population-based study among English middle-aged and older adults. BMJ Open, 2017(7), e014592. doi: 10.1136/bmjopen-2016-014592

Jimenez, M., Wellenius, G., Subramanian, S., Buka, S., Eaton, C., Gilman, S., Loucks, E. (2019). Longitudinal associations of neighborhood socioeconomic status with cardiovascular risk factors: A 46-year follow-up study, Social Science \& Medicine, 2019(112574). https://doi.org/10.1016/i.socscimed.2019.112574.

Krencker, D. (1929). Die Trierer Kaiserthermen. Ausgrabungsbericht \& grundsaetzliche Untersuchungen der Roemischen Thermen. Augsburg, Benno Filser.

Koop, G. (2013). Analysis of economic data. $4^{\text {th }}$ Edition. Chichester, John Wiley \& Sons.

Lang, T. and Rayner, G. (2012). Ecological public health: the 21st century's big idea? British Medical Journal 2012, 345:e5466. doi: https://doi.org/10.1136/bmj.e5466.

Larsson, R. (1993). Case survey methodology: quantitative analysis of patterns across case studies. Academy of Management Journal, 36(6), 1515-1546. doi : 10.2307/256820

Leggett, W. (2014). The politics of behaviour change: nudge, neoliberalism and the state. Policy \& Politics, 42 (1), 3-19. doi: https://doi.org/10.1332/030557312X655576

Lobstein T., Baur L., Uauy R. (2004). Obesity in children and young people: a crisis in public health. Obesity Reviews (5), 4-85.

Marmot, M., Allen, J., Goldblatt, P., Herd, E. and Morrison, J. (2020). Build back fairer: The COVID-19 Marmot Review. The pandemic, socioeconomic and health inequalities in England. London: Institute of Health Equity.

Meusel, H. (1960). Die Verwaltung und Finanzierung der öffentlichen Bäder zur römischen Kaiserzeit, Cologne.

Mitchell (1988). British historical statistics, a century of change: Trends in UK statistics since 1900, https://researchbriefings.files.parliament.uk/documents/RP99-111/RP99-111.pdf 
Munda, G. (2004). Social multi-criteria evaluation: Methodological foundations and operational consequences. European Journal of Operational Research, 158(3), 662-677. doi: 10.1016/S0377$2217(03) 00369-2$

Munda, G. (2008). Social Multi-Criteria Evaluation for a sustainable economy. Berlin, Heidelberg: Springer-Verlag Berlin Heidelberg. doi: 10.1007/978-3-540-73703-2

NCD-RFC (2017). Non-communicable disease risk factor collaboration worldwide trends in body-mass index, underweight, overweight, and obesity from 1975 to 2016: a pooled analysis of 2416 population-based measurement studies in 128.9 million children, adolescents, and adults. Lancet, 390(10113), 2627-2642. doi: 10.1016/S0140-6736 (17)32129-3.

NCD-RFC (2020). Non-communicable disease risk factor collaboration, UK country profile, http://www.ncdrisc.org/country-profile.html (290420).

Nielsen, I. (1990) Thermae et balnea: the architecture and cultural history of Roman public baths. Aarhus Universitet, Aarhus University Press.

Novell, L., Norris J., White D., Moules N. (2017). Thematic analysis: Striving to meet the trustworthiness criteria. International Journal of Qualitative Methods, 16(1). doi:10.1177/1609406917733847

Oetelaar (2014). Reconstructing the Baths of Caracalla. Digital Applications in archaeology and cultural heritage 1(2), 45-54.

ONS (2020). Deaths involving COVID-19 by local area and socioeconomic deprivation: deaths occurring between 1 March and 17 April 2020. Office for National Statistics, Statistical Bulletin. https://www.ons.gov.uk/peoplepopulationandcommunity/birthsdeathsandmarriages/deaths/ bulletins/deathsinvolvingcovid19bylocalareasanddeprivation/deathsoccurringbetween 1 march and17april.

ONS (2020). Regional gross disposable household income, UK: 1997 to 2017. Office for National Statistics.

https://www.ons.gov.uk/economy/regionalaccounts/grossdisposablehouseholdincome/bullet ins/regionalgrossdisposablehouseholdincomegdhi/1997to2017

OCSI (2018). Local insight profile for Cirencester CP. Oxford, Oxford consultants for social inclusion. https://www.gloucestershire.gov.uk/media/2087434/cirencester.pdf

Park, B., Lee, Y. (2020). Upcoming aging society and men's health: Focus on clinical implications of exercise and lifestyle modification. World Journal of Men's Health, 38(1), 24-31. 
Park, M., Falconer, C., Viner, R, \& Kinra, S. (2012). The impact of childhood obesity on morbidity and mortality in adulthood: a systematic review. Obesity reviews, 13(11), 985-1000.

Pasquarella, C., Veronesi, L., Napoli, C., Castaldi, S., Pasquarella, M., Saccani, E. \& Liguori, G. (2013). Swimming pools and health-related behaviours: Results of an Italian multicentre study on showering habits among pool users. Public Health, 127(7), 614-619.

Platner, S. (1929). A Topographical Dictionary of Ancient Rome. Thomas Ashby (Ed). London, Humphrey Milford. Oxford University Press. 1929. Perseus Digital Database (2020). Tufts University.

http://www.perseus.tufts.edu/hopper/text?doc=Perseus\%3Atext\%3A1999.04.0054\%3Aentry \%3Dthermae-antoninianae

Petersén, A. Olsson, J. (2015). Calling evidence-based practice into question: acknowledging phronetic knowledge in social work. The British Journal of Social Work, 45(5), 1581-1597. doi: 10.1093/bjsw/bcu020

Public Health England (2017). Guidance: Health matters: obesity and the food environment. https://www.gov.uk/government/publications/health-matters-obesity-and-the-foodenvironment/health-matters-obesity-and-the-food-environment--2

Ramidus Consulting Limited. (2017). London Office Policy Review 2017. file:///C:/Users/ad4385/AppData/Local/Temp/london office policy review 2017 final 170 6 07.pdf

Raworth, K. (2017). Doughnut economics: seven ways to think like a 21st-century economist. White River Junction, VT, Chelsea Green Publishing.

Reimers, A., Wagner, M., Alvanides, S., Steinmayr, A., Reiner, M., Schmidt, S. \& Woll, A. (2014). Proximity to sports facilities and sports participation for adolescents in Germany. PLoS One 9(3).

RCHME (1976). Royal Commission on Historical Monuments of England: Bagendon in ancient and historical monuments in the county of Gloucester Iron Age and Romano-British monuments in the Gloucestershire Cotswolds. British History Online, pp. 6-9. London, Her Majesty's Stationery Office. http://www.british-history.ac.uk/rchme/ancient-glos/pp6-9

Schram, S., Flyvbjerg, B., Landman, T. (2013). Political, political science: a phronetic approach, New Political Science, 35(3), 359-372. doi: 10.1080/07393148.2013.813687

Segen's Medical Dictionary. (2011). https://medical-dictionary.thefreedictionary.com/morbidity 
Silva, Z., Rebelo, M., Manuela M., Silva, M., Alves, A., da Conceição C., Almeida, A., Aguiar, F., de Oliveira, A.; Nogueira, A.; Pinhal, H.; Aguiar, P.; Cardoso, A. (2012). Trihalomethanes in Lisbon indoor swimming pools: occurrence, determining factors, and health risk classification. Journal of Toxicology and Environmental Health, Part A: Occupational and Environmental Health Issues in Portugal, 75(13-15), 878-892.

Sloggett, A. \& Joshi, H. (1994). Higher mortality in deprived areas: community or personal disadvantage? British Medical Journal, 309, 1470.

Sports England (2020). Data access portal for Sports Facility data, Active Places Power and Local Insight tool. https://www.sportengland.org/know-your-audience/data

Staines, C., \& Ozanne-Smith, J. (2017). Drowning deaths between 1861 and 2000 in Victoria, Australia. World Health Organization. Bulletin of the World Health Organization, 95(3), 174-181.

Steel, N. et al. (2018). Changes in health in the countries of the UK and 150 English Local Authority areas 1990-2016: a systematic analysis for the Global Burden of Disease Study 2016. The Lancet, 392(10158), 1647-1661.

Stempski, S., Liu, L., Grow, H., Pomietto, M., Chung, C., Shumann, A., Bennett, E. (2015). Everyone Swims: A Community Partnership and Policy Approach to Address Health Disparities in Drowning and Obesity. Health Education and Behavior, 42, 106-114. doi: $10.1177 / 1090198115570047$

van Sluijs, E. M., McMinn, A., \& Griffin, S. (2007). Effectiveness of interventions to promote physical activity in children and adolescents: systematic review of controlled trials. BMJ (Clinical research ed.), 335(7622), 703. doi: 10.1136/bmj.39320.843947.BE.

Veblen, T. (1919). Vested interests and the common man. Originally published as Vested interests and the state of the industrial arts. New York, B. W. Heubsch. Online edition: http://www.eleganttechnology.com/resource/Vested Interests.pdf

Ward, R. (1992). Women in Roman baths. Harvard Theological Review, 85(2), 125-147.

Wicker, P., Hallmann, K. \& Breuer, C. (2013). Analyzing the impact of sport infrastructure on sport participation using geo-coded data: Evidence from multi-level models. Sport Management Review, 16 (1), 54. doi: 10.1016/j.smr.2012.05.001.

Yawn, L. (2013). Public access, action and display in Rome of the later anni mille. In Perspectives on public space in Rome from antiquity to the present day. E., Smith and J. Gedeyne (Eds). Ashgate e-book. 
Yegül, F. (1992). Baths and bathing in classical antiquity. New York, Architectural History Foundation.

Yegül, F. (2010). Bathing in the Roman World. New York, Cambridge University Press.

Zanker, P. (2010). By the emperor for the people: popular architecture in Rome. The emperor and Rome: space, representation, and ritual, Vol. 35 Ch2, p45-87). B. Ewald, \& C. Noreña, (Eds) Cambridge, Cambridge University Press. 